\title{
Nuevas perspectivas de la costumbre en el Derecho Administrativo
}

\author{
$M^{a}$ del Pilar Bensusan Martín \\ Profesora Titular de Derecho Administrativo \\ Universidad de Granada
}

\begin{abstract}
SUMARIO: I. INTRODUCGIÓN. II. LA COSTUMBRE EN EL DERECHO ADMINISTRATIVO. 1. Existencia de la costumbre en el Derecho Administrativo. 2. Significado de la costumbre en Derecho Administrativo. A) Costumbre extra legem o praeter legem. B) Costumbre secundum legem. C) Costumbre contra legem. 3. Distinción entre costumbre, prácticas administrativas y precedente administrativo. 4. Supuestos de costumbre en Derecho Administrativo. A) Costumbre extra legem que opera como fuente en virtud de remisión expresa por la ley escrita. B) Costumbre extra legem que opera como fuente supletoria en ausencia de remisión legal expresa. G) Supuestos de costumbre contra legem: su carencia de validez. III. CONCLUSIONES. IV. BIBLIOGRAFÍA.
\end{abstract}

\section{RESUMEN.}

Permitiendo la perspectiva estatutaria entender la importancia de la costumbre como fuente del Derecho Administrativo, toda vez que permite la superación del enfoque del Estado como simple aparato organizado para el ejercicio del poder y, como tal, único protagonista de la producción del Derecho, la presencia de la colectividad social en el sistema de producción de fuentes es innegable. Partiendo de ello, y, a pesar de su limitada presencia en Derecho Administrativo, la costumbre únicamente admisible en nuestro Derecho va a ser la extra legem o praeter legem, esto es, aquella que opera como fuente en virtud de remisión expresa por ley escrita y la que opera como fuente supletoria en ausencia de remisión legal expresa. Entre los supuestos de la primera modalidad pueden aislarse y distinguirse las auténticas normas consuetudinarias en Derecho Administrativo, que surgen cuando el legislador se remite directamente a ellas considerándolas pura y simplemente como costumbre. Mientras que, entre los supuestos de la segunda modalidad, la presencia de la costumbre 
es, o ha sido menor, aunque no inexistente. En definitiva, debe reconocerse la existencia de la costumbre -mayormente local- que pervive y convive con la ordenación positiva como exponente de la conciencia jurídica del pueblo y que como tal tiene contrastada presencia en distintos sectores e instituciones del Derecho Administrativo.

Palabras clave: Costumbre, Derecho Administrativo, fuentes del Derecho, extra legem, secundum legem, contra legem.

\section{ABSTRACT.}

Allowing for statutory perspective to understand the importance of custom as a source of administrative law, since it allows to overcome the state as a simple approach for the organized apparatus of power and, as such, the only star of the production of law, presence of the social community in the production system of sources is undeniable. On this basis, and despite its limited presence in administrative law, custom only permissible in our law will be the extra legem or praeter legem, that is, one that operates as a referral source under express written law and which operates as an extra source in the absence of express statutory reference. Among the assumptions of the first embodiment can be isolated and distinguished from the true customary law in administrative law, which arise when the legislature is forwarded directly to considering them simply as usual. While among the assumptions of the second embodiment of the present practice is or has been lower, but not nonexistent. In short, recognize the existence of -mostly local- custom that lives on and lives with positive management as a representative of the legal consciousness of the people and as such has proven presence in various sectors and institutions of the Administrative Law.

Key words: Custom, Administrative Law, sources of law, extra legem, secundum legem, contra legem.

\section{INTRODUGGIÓN}

Los orígenes del Derecho consuetudinario se entierran en los mismos orígenes de lo que entendemos por sociedad, toda vez que una costumbre es un hábito adquirido por la práctica frecuente de un acto por la colectividad. Según el Diccionario de la Real Academia Española de la Lengua costumbre (Del lat. cosuetumen, por consuetūdo - Ĭnis), significa "Hábito, modo habitual de obrar o proceder establecido por tradición o por la repetición de los mismos actos y que puede llegar a adquirir fuerza de precepto"l. Y es que el origen mismo de la palabra designa lo 
que se ha hecho obligatorio por el uso $^{2}$. Hasta el siglo XIII la palabra consuetudines servía para designar las contribuciones debidas al señor y al sacerdote, ya que no existían títulos para exigirlas, esto es, contribución por uso, y es por extensión por lo que se extiende a toda regla jurídica consagrada por el uso. Por su parte, dice el Código Civil ${ }^{3}$ en su artículo 1.1 que "Las fuentes del ordenamiento jurídico español son la ley, la costumbre y los principios generales del derecho", para añadir en su artículo 1.3 que "La costumbre sólo regirá en defecto de ley aplicable, siempre que no sea contraria a la moral o al orden público y que resulte probada. Los usos jurídicos que no sean meramente interpretativos de una declaración de voluntad, tendrán la consideración de costumbre" . Y es que en el ordenamiento jurídico español no sólo existe la posibilidad de producción de normas jurídicas como fruto de la voluntad reflexiva del Estado ${ }^{5}$, sino que asimismo no puede negarse la posibilidad de que existan normas con un origen distinto y no escrito. En este orden de cosas se inscribe la consagración por el Código Civil de fuentes del Derecho subsidiarias de la ley escrita, entre ellas la costumbre, como derecho que vive en la conciencia jurídica del pueblo ${ }^{6}$, y que, por tanto, se aplicará solamente en defecto de ley aplicable, siempre y cuando no sea contraria ni a la moral ni al orden público y resulte probada ${ }^{7}$.

El origen de la costumbre, por tanto, es siempre popular, por ello DE CASTRO restringe el concepto de costumbre a la creada ex factis por las agrupaciones socia-

\footnotetext{
${ }^{1}$ Diccionario de la Real Academia Española de la Lengua, vigésima segunda edición, 2001, pág. 392.

2 WALINE, Marcel, L'individualisme et le Droit, Ed. Domat-Montchrestien, 1949, pág. 252.

${ }^{3}$ LEG $1889 \backslash 27$.

${ }^{4}$ Es comúnmente aceptada por la doctrina la aplicación al Derecho público de lo dispuesto en el título preliminar del Código Civil, a este respecto, vid., BASSOLS COMA, Martín, "Reflexiones sobre el nuevo título preliminar del Código Civil; planteamientos jurídico-administrativos", Revista Española de Derecho Administrativo, núm. 11, 1976, págs. 585 y sigs.

${ }^{5}$ GARRIDO FALLA, Fernando, "Las fuentes no escritas del Derecho en el Derecho Administrativo", Revista de Estudios de la Vida Local, núm. 97, enero-febrero 1958, pág. 3, y MORELL OCAÑA, Luis, "La costumbre y los principios jurídicos generales en el Derecho Administrativo", Documentación Administrativa, núm. 195, julio-septiembre 1982, pág. 22.

${ }^{6}$ BIELSA, Rafael, Legislación administrativa argentina, tomo I, Buenos Aires, 1938, pág. 32.

${ }^{7}$ Sobre el carácter estrictamente supletorio de la costumbre, vid. las sentencias, entre otras, del Tribunal Supremo de 15 de noviembre de 1961 (RJ 1961 \4365) y de 3 de diciembre de 1981 (RJ 1981 \5313) sobre costumbres en materia laboral. Señala esta última que "si bien es cierto por lo que resulta de lo actuado en los autos, la realidad de una situación de hecho tolerada en lo relativo al comienzo de la jornada laboral nocturna en el ramo de panadería a las dos horas de la mañana, con el beneplácito o consentimiento de la autoridad administrativa laboral en ciertos casos, ello no puede generar la base sobre la que fundar la tesis de la existencia de una costumbre o uso con el efecto juridico de constituir una fuente de derecho reguladora del problema cuestionado en el proceso, pues aunque en nuestro ordenamiento legal sea en efecto la costumbre uno de los elementos integrantes del sistema de fuentes establecido en el artículo 1 del Código Civil, allí sólo se reconoce ese carácter a la costumbre preter legen, según revela el párrafo 3 del mismo al decir que la costumbre sólo regirá en defecto de ley aplicable, cuando además no sea contraria a la moral o al orden público y resulte pro-
} 
les externas al mecanismo estatal ${ }^{8} 9$, y la define como 'Aquella regla creada e impuesta por el uso de los moradores de un lugar y que logra valor jurídico al ser respetada por los órganos del Estado"10, la costumbre es siempre, por tanto, local o del lugar. Por su parte, CASTÁN estima que no es necesario que el uso proceda del pueblo mismo, toda vez que puede manifestarse a través de los órganos de la colectividad, o sea las autoridades administrativas ${ }^{11}$ y en la esfera del Derecho privado de los Tribunales ${ }^{12}$. En la misma línea ENNECERUS afirma que "si los Tribunales o las autoridades administrativas aplican tales usos en su jurisprudencia o práctica reiterada, dan con ello expresión a su reconocimiento a títulos de órganos de la colectividad"13. A juicio de ORTIZ DÍAZ, la aplicación de la costumbre por las autoridades administrativas o por los Tribunales no la priva nunca de su origen popular, de su carácter de fuente intuitiva y colectiva del Derecho, aunque cosa bien distinta son las costumbres propias de los funcionarios, que constituyen, strictu sensu prácticas administrativas, como también lo es el usus fori, entendido como práctica o modo usual con que los Tribunales suelen proceder para ordenar y desarrollar los juicios (prácticas judiciales) ${ }^{14}$. Para LAMBERT en ninguna de las fases históricas de nuestra civilización occidental el Derecho ha germinado exclusivamente de la conciencia popular sin la ayuda de la intervención de los Tribunales o de algún otro órgano de revelación, no obstante, esta intervención no oscurece en absoluto la procedencia del derecho consuetudinario ${ }^{15} 16$.

bada y ese carácter de subsidiaridad unido al respecto del sistema de prelación de fuentes, impide en este caso que pueda entrar en juego la costumbre, desde el momento que la materia sobre la que habrían de recaer sus efectos, se encuentra regulada por precepto legal concreto y específico, constituido por el art. 33 de la Reglamentación Nacional de Trabajo en la Industria de Panadería de 12 julio 1946, redactado de nuevo por Orden de 9 junio 1964 y en el que se señala como hora de comienzo de la jornada de trabajo las cuatro de la mañana, en pugna por consiguiente con la costumbre invocada, que por ello no puede tomarse en consideración" (Considerando Primero).

${ }^{8}$ DE CASTRO, Federico, Derecho Civil de España, Parte general, I, Madrid, 1955, págs. 465 y sigs.

${ }^{9}$ MORELL OCAÑA, Luis, "La costumbre...", op. cit., pág. 27, apunta que para el reconocimiento del Derecho consuetudinario es requisito necesario el origen extraestatal de la costumbre, esto es, que se trate de una norma que no ha nacido mediante una declaración de voluntad del correspondiente órgano del Estado.

${ }^{10}$ DE CASTRO, Federico, Derecho Civil..., op. cit., I, pág. 380.

${ }^{11}$ Acerca de la trascendencia del Derecho Civil en la formación de las instituciones del Derecho Administrativo, vid., MARTÍN-RETORTILLO BAQUER, Sebastián, El Derecho Civil en la génesis del Derecho Administrativo y de sus instituciones. Dos estudios, $1^{a}$ ed., Instituto García Oviedo, Universidad de Sevilla, Sevilla, 1960.

12 CASTÁN, José, Derecho Civil español, común y foral, Tomo I. Introducción y parte general, Vol. I. Ideas generales. Teoría de la norma jurídica, Madrid, 1951, pág. 304.

${ }^{13}$ ENNEGCERUS, Ludwig, Derecho Civil, Parte general, tomo I, Barcelona, 1934, pág. 156.

${ }^{14}$ ORTIZ DÍAZ, José, "El precedente administrativo", Revista de Administración Pública, núm. 24, septiembre-diciembre 1957, págs. 76 y 77.

${ }^{15}$ LAMBERT, Edouard, La fonction du Droit civil comparé, tomo I, V. Girad y E. Brière, París, 1903, pág. 130.

${ }^{16}$ Sobre la costumbre, vid. asimismo, LONGO, A., Della consuetudine come fonte del diritto pubblico, Palermo, 1892; RANELLETTI, Oreste, "La consuetudine come fonte del diritto pubblico interno", Revista di Diritto Pubblico, Milano, 1913; REGLADE, M., La coutûme en droit public interne, Burdeos, 1919; FORTI, U., Diritto Administrativo, vol. I, Napoli, 1931; BOBBIO, Norberto, La consuetudine como fatto normativo, Padova, 1940. 
La costumbre es, pues, una norma creada e impuesta por el uso social ${ }^{17}$ siendo necesarios dos elementos imprescindibles para que una conducta se califique como costumbre y tenga efectos jurídicos, un elemento material, esto es, el uso repetitivo y generalizado de actos del mismo contenido, por lo que sólo puede considerarse costumbre un comportamiento realizado por todos los miembros de una comunidad, debiendo tenerse en cuenta que cuando hablamos de comunidad, lo hacemos en el sentido más estricto posible, aceptando la posibilidad de la existencia de comunidades pequeñas; asimismo, esta conducta debe ser una que se repite a través del tiempo, es decir, que sea parte integrante del común actuar de una comunidad, por lo que difícilmente se puede considerar costumbre una conducta que no tiene antigüedad; y un elemento moral, es decir, la convicción de que tales actos se realizan bajo la presión de una obligación jurídica ${ }^{18}$, la conciencia de obligatoriedad, toda vez que todos los miembros de una comunidad deben considerar que la conducta común a todos ellos tiene una autoridad, de tal manera que no puede obviarse dicha conducta sin que todos consideren que se ha violado un principio que regulaba la vida de la comunidad. En ese sentido, es claro que existen conductas cuyo uso es generalizado y muy repetitivo pero que no constituyen costumbre en tanto no tienen emparejado el concepto de obligatoriedad, es lo que diferencia al Derecho de la moral y la religión. Sólo con la confluencia de estos dos elementos podemos considerar que nos encontramos frente a una costumbre como fuente de Derecho, es decir, fuente de derechos y deberes. Para TESAURO el fundamento de la obligatoriedad jurídica de la costumbre hay que buscarlo en la Constitución o en la ley que reconozca la idoneidad de esta fuente del Derecho, aunque ello no las convierte en elemento constitutivo de la costumbre, al igual que la Constitución no es elemento de la ley por el hecho de que ésta sea dictada en la forma y con los límites que la Constitución establece ${ }^{19}$.

Tradicionalmente la costumbre se clasifica en costumbre secundum legem, según la ley, que corrobora y desenvuelve los preceptos de la ley, extra legem o praeter legem, supletoria de la ley, y contra legem, contraria a la ley, que se opone a ella, no teniendo esta última sentido en nuestro ordenamiento jurídico ${ }^{20}$.

\footnotetext{
17 DE CASTRO, Federico, Derecho Civil..., op. cit., I, pág. 374.

${ }^{18}$ Este elemento se conoce con el nombre de opinio iuris seu necessitatis. Para FERRARI, Giusepe, Introduzione allo Studio sul Diritto pubblico consuetudinario, Milano, 1950, pág. 61, la opinio iuris y la opinio necessitatis son dos cosas diferentes, la primera se refiere al sujeto que actúa, mientras que la segunda se refiere a la generalidad de la actuación, "con la opinio necessitatis quien actúa sabe, reconoce, constata de estar obligado a observar toda conducta dada; con la opinio iuris, en cambio, advierte que la misma conducta tendrá que ser observada por cualquier otro".

19 TESAURO, A., "Consuetudine", Rasegna di Diritto Pubblico, abril-junio 1955, pág. 195.

${ }^{20}$ Para FERRARI, Giuseppe, Introduzione allo Studio..., op. cit., pág. 126, no existe la autonomía conceptual de la costumbre secundum legem, ya que, limitada su función a interpretar la ley, no se puede hablar de fuente del Derecho sino de mero instrumento en el proceso interpretativo. Sin embargo, sí considera legítima la costumbre contra legem, al admitir que la costumbre es fuente del Derecho con la misma fuerza que la ley escrita (pág. 131).
} 


\section{LA COSTUMBRE EN EL DEREGHO ADMINISTRATIVO}

\section{Existencia de la costumbre en el Derecho Administrativo}

Sentado esto surge la cuestión de la existencia o no de la costumbre en el Derecho Administrativo, esto es, si verdaderamente tiene cabida en el ordenamiento jurídico-administrativo la posibilidad de rellenar sus lagunas ${ }^{21}$ mediante la costumbre o si su papel en Derecho Administrativo es tan nulo como usualmente se afirma ${ }^{22}$.

Hay para quien la admisión de la costumbre en Derecho Administrativo no presenta lugar a dudas, como es el caso de GASCÓN Y MARÍN, para quien siendo la costumbre fuente del Derecho y siendo el Derecho Administrativo una rama de aquél, debe concluirse que la costumbre es fuente del Derecho Administrativo $^{23}$. En idéntico sentido se expresa GONZÁLEZ PÉREZ al señalar que, estando la costumbre consagrada como fuente del Derecho en el Código Civil, es aplicable al Derecho Administrativo ${ }^{24}$.

Señala MORELL OCAÑA que se comprende que en la función creadora de reglas de Derecho se estableciera una previsión, casi teórica, relativa a la posible existencia de normas consuetudinarias, pudiendo existir en el Derecho Administrativo prácticas complementarias de la legalidad, como el precedente $^{25}$, o actitudes deformadoras de la misma, como el desuso o inaplicación de la norma, pero la atribución de la producción de normas a la creación reflexiva estatal, llevaba a una exclusión prácticamente total de la costumbre como fuente del Derecho Administrativo ${ }^{26}$. Sin embargo, una evolución conceptual permite contemplar la posición de la colectividad social en el sistema de fuentes del Derecho público, toda vez que el Estado no es sólo un aparato organizado para el ejercicio del poder, sino también soporte de una amplia pluralidad de grupos sociales que cuentan con un ius proprium, por lo que ya no se pue-

\footnotetext{
${ }^{21}$ A este respecto, vid., CLAVERO ARÉVALO, Manuel, "La doctrina de los principios generales del Derecho y las lagunas del ordenamiento administrativo", Revista de Administración Pública, núm. 7, eneroabril 1952, págs. 51 a 104.

${ }^{22}$ Una síntesis de todas las posiciones doctrinales puede verse en GARRIDO FALLA, Fernando, Tratado de Derecho Administrativo, vol. I, Madrid, 1980, pág. 321 y sigs.

${ }^{23}$ GASCÓN Y MARÍN, José, Tratado de Derecho Administrativo, vol. I, Madrid, 1941, pág. 94.

${ }^{24}$ GONZÁLEZ PÉREZ, Jesús, "El método en el Derecho Administrativo", Revista de Administración Pública, núm. 22, enero-abril 1957, pág. 58.

${ }^{25}$ Modo de entender y aplicar reiteradamente una norma por parte de la Administración.

${ }^{26}$ En este sentido, vid., MAYER, Otto, Droit Administratif Allemand, vol. I, París, 1903, pág. 168.
} 
de dejar la función del grupo social en el sistema de producción del Derecho en ese lugar absolutamente secundario que se otorgaba a la costumbre en su acepción tradicional, sino que asume modalidades diversas ${ }^{27}$. Y -añade- es precisamente la perspectiva estatutaria la que permite calibrar la importancia de la costumbre como fuente del Derecho Administrativo, porque permite superar el enfoque del Estado como simple aparato de poder y protagonista único de la producción del Derecho ${ }^{28}$.

Por su parte BIELSA define a la costumbre como el derecho que vive en la conciencia jurídica del pueblo y, por ello, la costumbre jurídico-administrativa es aquel derecho que surge espontáneo en la actividad ${ }^{29}$.

POSADA apunta que, si bien el ordenamiento administrativo es Derecho escrito, constantemente aparecen instituciones político-administrativas mantenidas por costumbres tradicionales que se sustentan con tenacidad ${ }^{30}$. Y GARCÍA OVIEDO afirma que negar fuerza a la costumbre en cualquier ordenamiento jurídico es cerrar los ojos a la realidad, toda vez que antes que la ley está la costumbre, pues el Derecho es un producto de la formación social. Añade, sin embargo, que el Derecho Administrativo es mayormente un Derecho escrito, por lo que el valor de la costumbre en Derecho Administrativo es subordinado, no debiendo nunca admitirse la costumbre contra legem ${ }^{31}$.

Por el contrario, Otto MAYER se opone a la admisión de la costumbre en el Derecho Administrativo, toda vez que éste es un Derecho fundamentalmente escrito y reflexivo, no teniendo en él cabida la costumbre porque, cuando la Administración no está vinculada a la ley, aparece el poder discrecional, cuya diferencia esencial respecto del Juez se basa en que éste ha de fundamentar siempre su sentencia en una norma, si no escrita, consuetudinaria ${ }^{32}$.

SANTAMARÍA PASTOR afirma la limitada o nula operatividad de la costumbre en Derecho Administrativo, toda vez que, aunque es uno de los tópicos más establemente aceptados en nuestra doctrina, es obligado reconocer, sin embargo, que, por una vez, el tópico científico posee un cumplido refrendo en la doctrina jurisprudencial contencioso-administrativa, apareciendo en escasí-

\footnotetext{
${ }^{27}$ MORELL OCAÑA, Luis, "La costumbre...", op. cit., págs. 22 y 23.

${ }^{28}$ MORELL OCAÑA, Luis, "La costumbre...”, op. cit., pág. 26.

${ }^{29}$ BIELSA, Rafael, Legislación administrativa..., op. cit., tomo I, Buenos Aires, 1938, pág. 32.

30 POSADA, Adolfo, Tratado de Derecho Administrativo, 2a ed., Madrid, 1923, pág. 174.

31 GARCíA OVIEDO, Carlos, Derecho Administrativo, Madrid, 1953, págs. 41 y 42.

32 MAYER, Otto, Droit Administratif..., op. cit., pág. 168.
} 
simas ocasiones para indicar su falta de valor vinculante. "Lo que ocurre -añade- es que el sólido prejuicio negativo acerca de la fuerza normativa de la costumbre ha terminado por difuminar la presencia de esta institución, reconduciendo su problemática a la de otra figura próxima, pero no idéntica (la del precedente) y el fundamento de su obligatoriedad a otra fuente, cuales son los principios generales del Derecho. Todo ello ha conducido a un creciente oscurecimiento de la temática del Derecho Administrativo consuetudinario"33.

Para ROYO VILLANOVA en el Derecho Administrativo los actos de la Administración suponen una actuación reflexiva, la de los funcionarios públicos, por lo que la idea de costumbre parece incompatible con el concepto propio de lo administrativo, no obstante, en la Administración local no sucede lo mismo, toda vez que la espontaneidad de la vida en los municipios hace que rebroten las instituciones municipales reguladas por la costumbre ${ }^{34}$.

GARCÍA DE ENTERRÍA afirma asimismo la existencia de la costumbre cuando señala que "el Derecho Administrativo es, como es común en todos los Derechos, un orden relacional, en el cual la Administración tiene una posición determinada, pero no la única relevante; frente a ella está la de todos los demás sujetos, de modo que sería abusivo intentar comprender la relación entera desde la perspectiva (racional, reflexiva, etc.) de la Administración únicamente. Más todavía: hay toda una esfera administrativa, la llamada "Administración corporativa", en que los particulares son miembros activos de la Corporación, miembros además dotados de un ámbito de autonomía en su actuación como tales", criticando además la tradición dogmática que ha pretendido excluir la costumbre en base a argumentos tales como "que el carácter racionalizado y reflexivo del ordenamiento administrativo excluye las normas de formación espontánea como es la costumbre; que el Derecho Administrativo es por esencia un Derecho del Estado, en tanto que la costumbre es un producto de la sociedad", para añadir que "Estas razones no son concluyentes. Por de pronto, ya sabemos que la racionalización y la reflexión son una tendencia en toda organización social, que es siempre la base de todo ordenamiento, pero que en cualquier organización, de cualquier clase, aun la más alquitarada y más abstracta, operan con mayor o menor amplitud tendencias irracionales y disfuncionales, resistencias y no sólo propósitos formales (esto es hoy un lugar común en la Sociología de la burocracia, frente a la clásica caracterización de

33 SANTAMARÍA PASTOR, Juan Alfonso y PAREJO ALFONSO, Luciano, Derecho Administrativo. La jurisprudencia del Tribunal Supremo, Madrid, 1989, págs. 107 y 108.

${ }^{34}$ ROYO VILLANOVA, Antonio, Elementos de Derecho Administrativo, tomo I, 24a ed., Valladolid, 1955, págs. 56 a 58. 
Max WEBER); también es un simplismo, por otra parte, identificar costumbre y espontaneidad, cuando es un hecho que al formar costumbres la comunidad opera con una opinio iuris vel necesitatis que por sí sola la dota de una especial autoconciencia. En fin, justamente en el ámbito del Derecho del Estado, concretamente en el Derecho Constitucional, es donde se produce la más importante y más extensa aplicación de la costumbre como fuente normativa"35.

Admitida, pues, mayoritariamente, la existencia de la costumbre en Derecho Administrativo, normalmente se le otorga un carácter de fuente absolutamente secundaria, sin embargo es objeto del presente estudio la constatación de supuestos de costumbre que evidencien que su papel en Derecho Administrativo no es tan nulo como usualmente se afirma ${ }^{36}$.

\section{Significado de la costumbre en Derecho Administrativo}

Para comprender el significado de la costumbre en Derecho Administrativo se hace imprescindible volver a la distinción entre las tres modalidades clásicas de costumbre: costumbre extra legem o praeter legem, costumbre secundum legem y costumbre contra legem.

\section{A) Costumbre extra legem o praeter legem}

Puede decirse que la costumbre extra legem o praeter legem engloba a su vez dos variedades distintas de costumbre: la costumbre que opera por remisión de la ley y la costumbre que opera en ausencia de remisión legal expresa para cubrir las lagunas de la norma escrita ${ }^{37}$. La primera de ellas no plantea problemas en Derecho Administrativo en tanto en cuanto existe normativa en nuestro orde-

35 GARCÍA DE ENTERRÍA, Eduardo y FERNÁNDEZ RODRÍGUEZ, Tomás-Ramón, Curso de Derecho Administrativo, Tomo I, 15ª ed., Civitas, Madrid, 2011, pág. 68.

${ }^{36}$ Lejos queda, sin embargo, el convencimiento de COLMEIRO cuando señalaba que "La costumbre es más poderosa en el Derecho administrativo que en el civil, porque las reglas son menos positivas, los intereses más variables y los accidentes y pormenores más numerosos y complicados. Así sucede con frecuencia que una ley general deje a salvo las Ordenanzas y reglamentos particulares de los pueblos" (COLMEIRO, Manuel, Derecho Administrativo español, tomo I, Imp. de Hilario Martínez, Madrid, 1850), y ello porque además de suplir las prescripciones de la norma resolviendo casos no previstos por ella, facilitaba el desenvolvimiento de la Administración ante la ausencia de desarrollo legislativo que no siempre podía satisfacerse con la oportunidad y exactitud conveniente. Sin embargo, el requerimiento de un Derecho extensísimo para esta rama del ordenamiento jurídico ha tenido sobrado cumplimiento en los siglos XX y XXI, de tal manera que el papel de la costumbre como auxilio y complemento de la ley ha perdido la virtualidad que le atribuía Colmeiro.

37 Siguiendo a SANTAMARÍA PASTOR. SANTAMARÍA PASTOR, Juan Alfonso y PAREJO ALFONSO, Luciano, Derecho Administrativo..., op. cit., págs. 108 a 116. 
namiento que remite la regulación de determinados aspectos a la costumbre, fundamentalmente local, por ejemplo, en materia de aguas, de aprovechamientos comunales, de caza y de organización y funcionamiento de determinadas entidades locales ${ }^{38}$, no debiendo olvidarse el carácter estrictamente supletorio de la costumbre, cuya aplicación debe quedar excluida en cuanto exista norma en la materia, aún reglamentaria. La segunda de las modalidades señaladas, esto es, la costumbre extra legem stricto sensu, aquella que opera en ausencia de remisión legal expresa para cubrir las lagunas de la norma escrita, no suele ser objeto de consideración por la doctrina, toda vez que su presencia es prácticamente nula en el Derecho Administrativo, pues, al operar fuera de la relación jurídico administrativa -ya que nace de los usos seguidos en las relaciones entre particulares-, es difícil que pueda actuar como fuente supletoria de tal Derecho y es escasa su aparición en la jurisprudencia contencioso-administrativa $^{39}$. GARCÍA DE ENTERRÍA recuerda que la costumbre extra legem es la única que admite nuestro Derecho ${ }^{40}$.

\section{B) Costumbre secundum legem}

En lo que respecta a la costumbre secundum legem -también llamada costumbre interpretativa- en el Derecho Administrativo, esto es, el modo habitual y uniforme de interpretar y aplicar una norma jurídica, debe ponerse de manifiesto primeramente su nula presencia en la jurisprudencia contencioso-administrativa. Como señala SANTAMARÍA PASTOR "no es aventurado afirmar que la doctrina jurisprudencial ha hecho suya, implícitamente, la tesis privatista que negaba a este tipo de costumbre toda eficacia vinculante, en base a lo dispuesto por el artículo 1.3 Gc (antes, artículo 6). Si se tiene en cuenta este

${ }^{38}$ La remisión por el ordenamiento jurídico-administrativo a la costumbre en determinados supuestos es admitida por la jurisprudencia de manera pacífica. A este respecto, vid., sentencias del Tribunal Supremo de 6 de diciembre de 1962 (RJ 1962\4653) y de 31 de enero de 1963 (RJ 1963\794).

39 Constan, no obstante, a favor, las sentencias del Tribunal Supremo, de 3 de marzo de 1958 (RJ 1958\957), relativa a una inscripción de aprovechamiento de aguas respecto a la que los regantes pretendían contar con un caudal mayor del concedido, señala el Alto Tribunal que "aunque en el título jurídico no constare el número de litros por segundo aprovechados, se suele autorizar a inscribir por el Ministerio de Obras Públicas como mínimo un litro por hectárea de tierra regable, lo que constituye una práctica administrativa que colma la laguna jurídica que al efecto existe..."; y la de 15 de marzo de 1963 (RJ 1963\1676), relativa al examen de un alumno de la Universidad, respecto a lo que el Tribunal Supremo afirma que "no existiendo una ordenación positiva especifica sobre la práctica de los exámenes académicos, hay que seguir la costumbre, que es fuente del Derecho, según el artículo 6 del Código Civil, en defecto de ley, extensivo al Derecho especial como es el administrativo, (...) y es lo consuetudinario (...) que sean los catedráticos o profesores especialistas encargados de Cátedra los que dirijan e intervengan directamente en los exámenes de las disciplinas académicas que desempeñan...".

${ }^{40}$ GARCÍA DE ENTERRÍA, Eduardo y FERNÁNDEZ RODRÍGUEZ, Tomás-Ramón, Curso de Derecho Administrativo..., op. cit., I, pág. 69. 
punto de partida dogmático, es lógico que la validez de la costumbre secundum legem es un tema que ni siquiera llegue a suscitarse formalmente" 41 . No obstante, este autor remite en esta cuestión, como exigencia de igualdad y seguridad en el tratamiento de los conflictos, al precedente administrativo, aunque advierte que son realidades diversas. Por su parte GARCÍA DE ENTERRIA, en consonancia con lo expresado supra, niega la admisión de la costumbre $s^{-}$ cundum legem en Derecho Administrativo ${ }^{42}$, lo cual viene avalado en el ordenamiento jurídico-administrativo por el propio Derecho positivo (artículo $54.1 \mathrm{c}$ ) de la Ley 30/1992, de 26 de noviembre, de Régimen Jurídico de las Administraciones Públicas y del Procedimiento Administrativo Común, RCL 1992\2512), que le niega eficacia vinculante al permitir que la Administración pueda separarse válidamente del criterio seguido en actuaciones precedentes únicamente con motivar el por qué se adopta una nueva interpretación. No obstante la falta de valor normativo de este tipo de costumbre, sí es cierto que la adopción por la Administración Pública de un determinado criterio en la aplicación de una norma sí posee un cierto valor vinculante para ella derivado de los principios de seguridad jurídica, de interdicción de la arbitrariedad de los poderes públicos y del principio de igualdad ante la ley.

\section{C) Costumbre contra legem}

Finalmente, en lo que se refiere a la costumbre contra legem o abrogatoria, tampoco existen menciones directas en la jurisprudencia contencioso-administrativa, al igual que ocurre con la costumbre secundum legem, no obstante su aparición es colateral a través de las referencias al precedente ilegal y al desuso o derogación ordinamental de las normas jurídicas. En Derecho Administrativo no se admite, pues, la costumbre contra legem. Sobre el precedente ilegal la jurisprudencia se pronuncia unánime y abundantemente rechazándolo ${ }^{43}$, aun-

\footnotetext{
${ }^{41}$ SANTAMARÍA PASTOR, Juan Alfonso y PAREJO ALFONSO, Luciano, Derecho Administrativo..., op. cit., pág. 110 .

42 GARGÍA DE ENTERRÍA, Eduardo y FERNÁNDEZ RODRÍGUEZ, Tomás-Ramón, Curso de Derecho Administrativo..., op. cit., I, pág. 69.

43 Entre otras muchas, las sentencias del Tribunal Supremo de 30 de septiembre de 1961 (RJ 1961 \3149); de 17 de abril de 1963 (RJ 1963\2261); de 14 de octubre de 1965 (RJ 1965\5137); de 24 de enero de 1966 (RJ 1966\3291); de 2 de marzo de 1967 (RJ 1967\1599); de 25 de enero de 1968 (RJ 1968\663); de 4 de julio de 1969 (RJ 1969\3961); de 21 de noviembre de 1969 (RJ 1969 \5059); de 5 de diciembre de 1969 (RJ 1969\5655); de 7 de mayo de 1971 (RJ 1971\3214; de 15 de octubre de 1971 (RJ 1971\4094); de 16 de octubre de 1971 (RJ 1971\4097; de 25 de febrero de 1972 (RJ 1972\1525; de 12 de junio de 1972 (RJ 1972\3492); de 18 de diciembre de 1972 (RJ 1972\5022); de 29 de enero de 1973 (RJ 1973\379); de 27 de abril de 1973 (RJ 1973\2072); de 11 de octubre de 1973 (RJ 1973\3582); de 7 de mayo de 1974 (RJ 1974\2337); de 24 de enero de 1975 (RJ 1975\695); de 23 de abril de 1975 (RJ
} 
que indirectamente, al negar el precedente no ajustado al ordenamiento jurídico, ha admitido el valor vinculante del precedente legal cuando es conforme a Derecho. La jurisprudencia que rechaza el precedente ilegal se produce fundamentalmente en relación al otorgamiento de licencias urbanísticas denegadas por no ajustarse al planeamiento, toda vez que el Tribunal Supremo desestima la argumentación de que se hayan otorgado otras licencias urbanísticas en condiciones similares, al tratarse de precedentes ilegales que en modo alguno deben vincular a la Administración Pública ${ }^{44}$. La admisión, pues, de

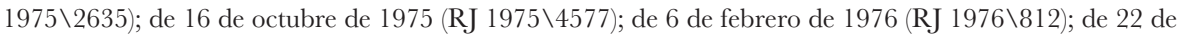
marzo de 1976 (RJ 1976 2092); de 21 de abril de 1977 (RJ 1977\2643); de 25 de abril de 1977 (RJ 1977\2647); de 20 de mayo de 1977 (RJ 1977\3220); de 10 de junio de 1977 (RJ 1977\3358); de 19 de octubre de 1977 (RJ 1977\4244); de 20 de octubre de 1977 (RJ 1977\3921); de 31 de octubre de 1977 (RJ 1977\4585); de 10 de noviembre de 1977 (RJ 1977\4140); de 13 de febrero de 1978 (RJ 1978\976); de 3 de marzo de 1978 (RJ 1978\863); de 11 de marzo de 1978 (RJ 1978\1122); de 10 de junio de 1978 (RJ 1978\2367); de 30 de junio de 1978 (dos) (RJ 1978\3154 y RJ 1978\3155); de 3 de abril de 1979 (RJ 1979\1562); de 8 de mayo de 1979 (RJ 1979\2387); de 6 de junio de 1979 (RJ 1979\2683); de 27 de junio de 1979 (RJ 1979\2990); de 11 de diciembre de 1979 (RJ 1979\4716); de 12 de diciembre de 1979 (RJ 1979 4721); de 9 de febrero de 1980 (RJ 1980\649); de 7 de marzo de 1980 (RJ 1980\2101); de 8 de abril de 1980 (RJ 1980 2299); de 12 de junio de 1980 (RJ 1980\3182); de 20 de octubre de 1980 (dos) (RJ 1980\3919 y RJ 1980\3923); de 17 de diciembre de 1980 (RJ 1980\5060); de 23 de diciembre de

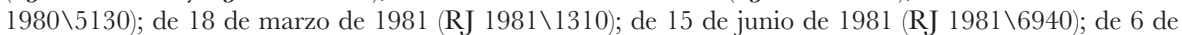
julio de 1981 (RJ 1981\3155); de 8 de febrero de 1982 (RJ 1982\889); de 26 de febrero de 1982 (RJ 1982\1646); de 2 de abril de 1982 (RJ 1982\2381); de 21 de junio de 1982 (RJ 1982\4824); de 8 de abril de 1983 (RJ 1983\2083); de 6 de febrero de 1984 (RJ 1984\605); y de 26 de Abril de 1984 (RJ 1984\2577). La jurisprudencia del Tribunal Constitucional ha ratificado expresamente el apartamiento de la Administración del precedente ilegal por su falta de vinculación al afirmar que "la equiparación en la igualdad, que por propia definición puede solicitar el ciudadano que se siente discriminado, ha de ser dentro de la legalidad y sólo ante situaciones idénticas que sean conformes al ordenamiento jurídico, pero nunca fuera de la legalidad, con extensión indebida a la protección de situaciones ilegales, ni tampoco para convalidar jurídicamente los defectos imputables a la siempre limitada eficacia en el plano de los hechos que las actuaciones de los poderes públicos desplieguen para el restablecimiento de la realidad fisica o jurídica alterada ilegalmente" (sentencia del Tribunal Constitucional de 16 de junio de 1982).

${ }^{44}$ Los argumentos del Tribunal Supremo se basan primeramente en que los conflictos que puedan surgir en estos casos entre el principio de igualdad y el de legalidad deben resolverse a favor del principio de legalidad. Señala el Alto Tribunal en su sentencia de 21 de abril de 1977 (RJ 1977\2643) que "Oue si bien es cierto, como dice la representación del accionante, que en diversas calles y hasta en la que está situada la que es objeto de la presente controversia, existen inmuebles con mayores alturas, como se ha acreditado de una manera minuciosa en la diligencia de reconocimiento judicial, practicada por esta Sala, ello no puede amparar la pretensión recurrente en el principio de igualdad ante la Ley, de todos los administrados, ... si bien el principio aludido no implica que se sigan otorgando licencias que vulneren la legalidad vigente en el ayuntamiento en cuestión por el hecho de que la Corporación de que se trate hubiera otorgado otras -STS de 29 de noviembre de 1968, y de 4 de julio de 1969-, pues como reiteradamente ha declarado dicho Alto Tribunal, el primer principio a tenerse en cuenta es el de la legalidad, no pudiéndose olvidar u omitir el mismo en aras del de igualdad para que el principio aducido tenga operatividad se necesita que la legalidad vigente permita lo edificado, pues del hecho de que varias veces se hubiera conculcado ésta última, no puede racionalmente inferirse que tenga que seguirse conculcando la legalidad, pues entre la fricción de ambos principios, es el de la legalidad el que ha de privar; por todo lo cual, procede desestimar el recurso interpuesto". Y, en segundo lugar, porque aceptar la eficacia vinculante del precedente ilegal supondría la consagración de una vía anómala de derogación de normas escritas mediante la acepta- 
precedentes ilegales supondría consagrar una forma alternativa y anómala de derogar las normas escritas mediante la aceptación de una costumbre o práctica ilegal. En lo que se refiere al desuso, desuetudo o derogación ordinamental de las normas jurídicas, es decir, a la inobservancia de las normas a causa de un cambio de las circunstancias que promovieron su aprobación, aunque el Código Civil no admite el desuso como causa de derogación de las leyes ${ }^{45}$, es cierto que existen multitud de normas escritas que han dejado de aplicarse sin haber sido expresamente derogadas, lo cual aparece con mayor obviedad en el Derecho Administrativo, toda vez que está constituido por un numerosísimo conjunto de normas muy expuestas a las transformaciones de la realidad. El artículo 129.3 de la Ley de Procedimiento Administrativo de 17 de julio de 1958 (RCL 1958\1258) quiso acabar con la incertidumbre de las derogaciones implícitas al disponer que "No podrá formularse ninguna propuesta de nueva disposición sin acompañar al proyecto la tabla de vigencias de disposiciones anteriores sobre la misma materia, y sin que en la nueva disposición se consignen expresamente las anteriores que han de quedar total o parcialmente derogadas", aunque pocas de ellas han seguido esta técnica derogatoria expresa hasta la derogación de este precepto por la Disposición Derogatoria Única.1.d) de la Ley 50/1997, de 27 de noviembre, de Organización, Competencia y Funcionamiento del Gobierno (RCL 1997 2817 ). Sobre la desuetudo como causa abrogatoria de las normas GARCÍA DE ENTERRÍA ha precisado que "En la lógica del sistema normativo el desuso no puede admitirse fácilmente, porque pondría en cuestión el valor mismo de las normas escritas y, por ende, de los centros políticos capaces de producirlas; la norma debe valer por encima de su aplicación concreta, o incluso de su violación o inaplicación; más aún: sólo porque su razón de valer está sobreordenada o es trascendente a la aplicación puede ésta exigirse e imponerse, es decir, más sencillamente aún, la norma es verdadera norma. Pero es también un hecho que son constantes los ejemplos de normas que dejan un día de aplicarse sin que hayan sido desplazadas o derogadas por otras nuevas. La explicación se encuentra de nuevo en el carácter global y fáctico del ordenamiento, del que

ción de una costumbre o práctica ilegal. Afirma la sentencia del Tribunal Supremo de 11 de marzo de 1978 (RJ 1978\1122) que el reconocimiento del precedente ilegal conllevaría "el reconocimiento de un valor normativo a hechos consumados contra legem, carente de todo apoyo en el ordenamiento juridico y que queda desvirtuada ante la obvia observación de que los preceptos legales (...) tan solo se derogan por otros posteriores, sin que pueda prevalecer la práctica en contrario, según disposición taxativa contenida en el entonces artículo 5 del Código Civil'; y la sentencia del Alto Tribunal de 27 de noviembre de 1979 (RJ 1979\4066) señala que "tal praxis implicaría admitir una fuente derogatoria del Derecho prohibida por el artículo 5 del Código Civil - 2, ap. 2 en el texto de 1974".

${ }^{45}$ Cuyo artículo 2.2 señala que "Las leyes sólo se derogan por otras posteriores". Al proscribir el legislador el desuso como forma de derogación, en pro de la seguridad jurídica, ocurre que las normas obsoletas continúan formalmente vigentes y los jueces y magistrados únicamente podrán inaplicarlas cuando sean contrarias a la buena fe, arbitrarias o atentatorias contra el principio de igualdad ante la ley. 
más atrás hemos hablado, No podrá hablarse, por hipótesis, de una derogación de la norma que deja de aplicarse por otra norma posterior concreta; pero deberá hablarse de una evolución del ordenamiento como conjunto que ha desconectado de él la norma en cuestión, por lo que ésta deja de valer como tal. Este es el mecanismo, y no el desuso abrogatorio, que ha de explicar el fenómeno indicado" 46 , se produce, por tanto, un desenganche fáctico del sistema general del ordenamiento (ejemplo de ello para este autor es la Constitución de 1931, de la cual no consta derogación expresa alguna, siendo evidente su abrogación no como consecuencia de un simple desuso, sino por encontrarse desligada del ordenamiento como organización social fáctica). No obstante todo lo dicho, la desuetudo ha tenido acogida en la jurisprudencia, que aprecia que, aunque una ley de las calificadas por la doctrina como obsoleta, esto es, aquella que por el cambio de circunstancias y desaparición de la razón de ser que la motivó no hubiera sido derogada formalmente, debe quedar privada de fuerza para subsistir dentro del bloque de la legalidad imperante en ese momento ${ }^{47}$.

\section{Distinción entre costumbre, prácticas administrativas y prece- dente administrativo}

La doctrina refiere la costumbre, las prácticas administrativas y el precedente administrativo muchas veces sin establecer diferencias entre ellas, lo que puede inducir a confusión, por lo que ha intentado esclarecerse por algunos autores.

\footnotetext{
${ }^{46}$ GARCÍA DE ENTERRÍA, Eduardo y FERNÁNDEZ RODRÍGUEZ, Tomás-Ramón, Curso de Derecho Administrativo..., op. cit., I, pág. 71.

${ }^{47}$ Afirma la sentencia del Tribunal Supremo de 25 de mayo de 1983 (RJ 1983\3434) que "En cuanto al otro argumento empleado por la empresa accionante, referido a la extranjería de la empresa adjudicataria, tampoco puede desestimar la estimación de su recurso, puesto que la ley invocada para ello, la de 24 de noviembre de 1939, de Ordenación y Defensa de la Industria Nacional, responde a unos principios -los autárquicos que aquella época- totalmente superados, por un cambio total de las circunstancias producido no ahora, sino desde hace mucho tiempo, dentro del propio Régimen Político que promulgó aquella Ley, en el cual, por su duración, se produjeron evoluciones notables en lo económico, lo que era inevitable, como la recogida por el Decreto-Ley de 21 de julio de 1959, con su plan de estabilización, y sus inmediatas secuelas de supresión de organismos de intervención (Decretos de 12 de septiembre y 10 de diciembre de 1959), evolución que se acentuó aún más con los Planes de Desarrollo, de carácter indicativo para el sector privado, iniciados con las directrices y medidas preliminares marcadas por el Decreto de 23 de noviembre de 1962, que se consolidan con la Ley de 28 de diciembre de 1963, aprobatoria del primer Plan; circunstancias que, en su conjunto, vienen a evidenciar que la Ley invocada de 1939 es, en la actualidad, aunque no hubiera sido derogada formalmente, una ley de las calificadas por la doctrina de "obsoletas", esto es, una Ley que por el cambio de circunstancias y desaparición de la razón de ser que la motivó, queda privada de fuerza para subsistir dentro del bloque de la legalidad imperante en estos momentos".

48 Supuesto especial de desuetudo en Derecho Administrativo lo constituye la tolerancia por parte de la Administración de prácticas de los administrados contrarias al ordenamiento jurídico, toda vez que las normas que son reiteradamente contravenidas por los administrados llegan a perder su vigencia en la práctica, aunque formalmente sigan vigentes y sin perder de vista que la Administración puede en cualquier momento cambiar de criterio y proceder de nuevo a su aplicación (vid. al respecto, voz costumbre, Enciclopedia Jurídica Básica, vol. II, Ed. Civitas, Madrid, 1995, pág. 1774).
} 
GARRIDO FALLA señala que usualmente el lugar de la costumbre en Derecho Administrativo lo van a ocupar las prácticas administrativas, toda vez que los discutibles ejemplos que proporciona el Derecho positivo al respecto pueden clasificarse en dos grupos (costumbres que regulan el funcionamiento de instituciones surgidas espontáneamente en la historia y costumbres que regulan las relaciones entre particulares, aunque, por razón de la materia, tales relaciones se encuentran íntimamente conectadas con el interés público), y en ninguno de estos dos grupos aparece la relación jurídico-administrativa que se da entre la Administración y los particulares o administrados, por lo que dificilmente en Derecho Administrativo pueden darse los supuestos necesarios para que surja la costumbre con sentido análogo al que tiene en Derecho privado, esto es, como fuente del Derecho independiente de la voluntad estatal ${ }^{49}$, por ello, la costumbre en Derecho Administrativo sólo tiene vigencia respecto a los dos mentados grupos -resultando necesario que tal costumbre haya sido reconocida por la ley, y, una vez reconocida, no podrá ser derogada por normas de inferior rango formal-, mientras que en lo que se refiere a las relaciones jurídicas entre la Administración y los administrados, el papel de la costumbre puede venir desempeñado por las prácticas administrativas ${ }^{50}$. También ROYO VILLANOVA se pronuncia sobre la sustitución del valor de la costumbre por el de las prácticas administrativas ${ }^{51}$. Asimismo para POSADA las prácticas administrativas tienen una importancia fundamental en la teoría de las fuentes ${ }^{52}$. La obligatoriedad de las prácticas administrativas -refiere GARRIDO- surge allí donde haya podido crearse un principio de apariencia jurídica que induzca al administrado a creer correcta una actuación suya en un sentido determinado ${ }^{53}$. Para este autor, las prácticas administrativas que interesan no son unos simples modos de hacer, operaciones técnicas o de tramitación material de los expedientes, que carecen de relevancia, sino aquellas de cuya observancia pueden deducirse beneficios o perjuicios para situaciones jurídicas individualizadas, de ahí que no diferencie prácticas administrativas y precedente.

\footnotetext{
${ }^{49}$ GARRIDO FALLA, Fernando, "Las fuentes no escritas...", op. cit., págs. 10 a 12.

${ }^{50}$ GARRIDO FALLA, Fernando, "Las fuentes no escritas...", op. cit., pág. 14.

${ }^{51}$ ROYO VILLANOVA, Antonio, Elementos..., op. cit., pág. 37.

${ }^{52}$ POSADA, Adolfo, Tratado..., op. cit., pág. 175.

${ }^{53}$ Pudiendo apartarse la Administración de dicha obligatoriedad cuando se trate de materias en las que actúa con poderes reglados -por entender que la interpretación de la ley que se ha venido haciendo no es la correcta- y cuando se trate de materias en las que actúa con poderes discrecionales -por entender que los criterios hasta entonces aplicados son inoportunos o contrarios al interés público, si bien en este caso el cambio de criterio deberá de realizarse con carácter general para el futuro y no como derogación del criterio anterior para resolver un caso concreto- (GARRIDO FALLA, Fernando, "Las fuentes no escritas...", op. cit., págs. 13 y 14).
} 
Sin embargo, GARCÍA OVIEDO diferencia la costumbre de las prácticas administrativas, y ello en razón de su origen ${ }^{54}$, al igual que BIELSA, que separa la costumbre administrativa de la práctica o rutina burocrática, pero estos autores no distinguen las prácticas administrativas del precedente administrativo. Ello es debido -según ORTIZ DÍAZ- a que en la denominación de prácticas burocráticas o administrativas incluyen los usos de los funcionarios, la rutina administrativa y los precedentes, sin aparecer éstos con su adecuado y correcto significado ${ }^{55}$.

Por su parte PRESUTTI niega el carácter de fuente del derecho objetivo a las prácticas administrativas, afirmando que no constituyen norma jurídica y, por tanto, de ellas no nacen derechos ni obligaciones para los sujetos ajenos a la Administración, por lo que éstos no podrán exigir la observancia de las mismas, aunque los funcionarios sí deben respetarlas, incurriendo en responsabilidad jurídica en caso de inobservancia sin motivo justificado ${ }^{56}$; y RANELLETTI las considera fuentes de normas de administración puramente internas ${ }^{57}$. En la misma línea MIELE afirma que la práctica administrativa se forma a través de una conducta concordante seguida por los oficios de un ramo de la Administración en las materias de su competencia y que da origen a reglas de conducta cuya vigencia se limita exclusivamente a aquéllos ${ }^{58}$. Por el contrario, para ZANOBINI no puede considerarse a la práctica administrativa como una costumbre de carácter interno ${ }^{59}$ y para GIANNINI la práctica administrativa no es una fuente del Derecho Administrativo, es un uso de la Administración, repetido y consolidado, aunque con el pleno conocimiento de su carácter no normativo ${ }^{60}$.

Distingue ORTIZ DÍAZ entre costumbre y precedente administrativo primeramente porque la costumbre es derecho no escrito y el precedente es derecho escrito; añade que, aunque no existe una opinión unánime sobre el número de repeticiones que necesita un acto para producir una costumbre ${ }^{61}$ o un

${ }^{54}$ GARCÍA OVIEDO, Carlos, Derecho Administrativo, op. cit., págs. 41 y 42.

55 ORTIZ DÍAZ, José, "El precedente...", op. cit., pág. 77. Sobre el precedente, vid. también WERNER, Alain, "Le précédent administratif, source de légalité", A7DA, núm. 7-8, 1987, págs. 435 a 441.

56 PRESSUTTI, Enrico, Istituzioni di Diritto administrativo italiano, 2a ed., Roma, 1930, págs. 74 y 75.

${ }^{57}$ RANELLETTI, Oreste, “La consuetudine...", op. cit., pág. 163.

58 MIELE, G., Principi di Diritto administrativo, tomo I, Padova, 1953, pág. 113, y "Profilo della consuetudine nel sistema delle fonti del diritto interno", Stato e Diritto, 1943, pág. 8.

59 ZANOBINI, Guido, Corso di Diritto administrativo, vol. I, Milano, 1947, pág. 70.

${ }^{60}$ GIANNINI, Massimo Severo, Lezzioni di Diritto administrativo, vol. I, Milano, 1950, pág. 360.

${ }^{61}$ Señala DE CASTRO, Federico, Derecho Civil..., op. cit., I, pág. 328, que tanto las Partidas como el Código Civil determinan la necesidad de que el uso se concrete en un lugar, aunque no puede determinarse el número de actos ni el de años necesarios para la consolidación del uso, y que sólo se debe indicar que ha de ser tan antiguo, frecuente y constante como para crear la racional seguridad de su continuidad en el próximo futuro. 
precedente, la costumbre requiere, junto a la reiteración de los actos, cierta antigüedad, mientras que en el precedente administrativo no juega el factor tiempo ni la repetición de casos, toda vez que el precedente no se basa en la reiteración de actos sino en la concreción del principio de igualdad. "Le falta, pues, -dice- el elemento material de la costumbre, el uso. Basta por tanto un "precedente" para que pueda invocarse la autoridad del mismo. A pesar de las diferencias señaladas -concluye-, el precedente y la costumbre ofrecen parecido en cuanto a su modo de formación, ambos son un producto de un proceso de inducción. De casos concretos indúcese la norma o regla general, a diferencia de la ley que establece por vía de generalidad y de la que dedúcese la aplicación a supuestos específicos y particulares" ${ }^{\prime \prime 2}$.

Asimismo diferencia ORTIZ DÍAZ entre precedente y prácticas administrativas, constituyendo estas últimas meras normas usuales de carácter y eficacia puramente interna para la Administración, derivadas de principios de técnica administrativa o de buena administración, que los funcionarios siguen en el desarrollo de su actividad, esto es, su estilo corriente de proceder, las tradiciones propias de los empleados, la rutina administrativa ${ }^{63}$; mientras que el precedente administrativo es algo más, toda vez que implica la resolución sustantiva de la Administración sobre cuestiones sometidas a la misma y generadora de derechos e intereses para los particulares ${ }^{64}$.

SANTAMARÍA PASTOR distingue y relaciona a su vez costumbre secundum legem y precedente administrativo, afirmando que toda costumbre puede considerarse, en cierta forma, como un precedente, pero que éste puede existir simplemente con un solo acto previo que interprete una norma en un determinado sentido, en tanto que la costumbre exige, por definición, una repetición en el tiempo de numerosos actos de idéntica significación interpretativa ${ }^{65}$. Aparte de la necesidad o no de reiteración en el tiempo, añade que el fundamento de su fuerza de obligar es distinto, mientras que en la costumbre es inmanente, esto es, se halla en su misma condición de fuente del Derecho, en el precedente es trascendente, es decir, se basa en el debido respeto al los principios generales de seguridad jurídica y de igualdad ante la ley. Advierte que no todo precedente es,

\footnotetext{
${ }^{62}$ ORTIZ DÍAZ, José, “El precedente...”, op. cit., pág. 78.

${ }^{63} \mathrm{El}$ esprit de suite de la burocracia, en palabras de POSADA, Adolfo, Tratado..., op. cit., pág. 175.

64 ORTIZ DÍAZ, José, "El precedente...", op. cit., pág. 80.

65 Además en este supuesto la práctica administrativa tampoco tiene valor de costumbre, toda vez que para que el efecto vinculante se produzca no es necesaria la existencia de una conducta de la Administración consolidada por su uso reiterado, siendo suficiente un único acto anterior, lo que remite al precedente administrativo.
} 
pues, una costumbre secundum legem, aunque matiza que puede aplicarse a este tipo de costumbre la jurisprudencia contencioso-administrativa relativa al precedente administrativo, que se decanta tradicionalmente por no admitir la eficacia vinculante del precedente ${ }^{66}$, aunque la invocación del principio de igualdad ante la ley ha permitido atinadamente a la jurisprudencia estimar recursos en base a la infracción de precedentes ${ }^{67}$, aunque haya sido con carácter puramente excepcional. Y es que la doctrina jurisprudencial ha señalado los cuatro requisitos necesarios para que el precedente resulte invocable en base al principio de igualdad ante la ley: la relación de identidad o semejanza entre el caso litigioso y el invocado como precedente ${ }^{68}$, la inexistencia de una razón de interés público que

66 SANTAMARÍA PASTOR, Juan Alfonso y PAREJO ALFONSO, Luciano, Derecho Administrativo..., op. cit., págs. 110 a 114. Refiere SANTAMARÍA que la actitud general de la jurisprudencia hacia el precedente y su eficacia vinculante ha sido tradicionalmente negativa, destacando a este respecto la sentencia del Tribunal Supremo de 31 de diciembre de 1914 (Colección Legislativa, núm. 143), que señalaba que "el acuerdo recaído en un expediente no obliga a la Administración a resolver las reclamaciones posteriores que ante la misma se promuevan en otros expedientes sobre casos análogos, en el mismo sentido en que lo hizo en la primera", así como las sentencias del Alto Tribunal de 6 de mayo de 1943 (RJ 1943\593), de 23 de junio de 1951 (RJ $1951 \backslash 1810$ ), de 5 de enero de 1957 (RJ 1957 \164) y de 11 de junio de 1962 (RJ 1962\2903), que expresamente refiere el "escaso o nulo valor vinculativo que la furisprudencia asigna al precedente". Más recientemente la jurisprudencia ha continuado afirmando que "el precedente no es fuente de Derecho por si solo" -sentencia del Tribunal Supremo de 16 de octubre de 1979 (RJ 1979\3476)-; que "como tiene declarado esta Sala en numerosas Sentencias por cuya profusión se hace inocuo citarlas dado su número, (el precedente) no vincula para nada" -sentencias del Tribunal Supremo de 13 de marzo de 1980 (RJ 1980\884) y de 25 de octubre de 1980 (RJ 1980\3801)-; que "sabido es que el precedente administrativo carece en nuestro ordenamiento jurídico de valor normativo, y el único precepto que se refiere a él de una manera directa es el artículo 43 LPA, que únicamente impone a la Administración la obligación de motivar los actos que se separen del criterio seguido en actuaciones precedentes" -sentencia del Tribunal Supremo de 18 de marzo de 1981 (RJ 1981\1310)-; que "los precedentes, en Derecho Administrativo, no constituyen fuente del mismo" -sentencias del Tribunal Supremo de 2 de abril de 1982 (RJ 1982\2381), que, a su vez cita las de 14 de abril de 1960, de 23 de junio de 1963, de 16 de octubre de 1965 (RJ 1965\4151), de 23 de noviembre de 1968 (RJ 1968\5431), de 18 de diciembre de 1972 (RJ 1972\5022), de 15 de junio de 1981 (RJ $1981 \backslash 6940)$ y de 30 de septiembre de 1981 (RJ 1981\3148)-; y que "los precedentes administrativos no vinculan a ésta jurisdicción, que ha de atenerse a los elementos contemplados en el litigio que se le somete para resolver y no a otros distintos" -sentencias del Tribunal Supremo de 9 de octubre de 1982 (RJ 1982\5750) y de 18 de noviembre de 1982 (RJ 1982\7004)-.

${ }^{67}$ La ya citada sentencia del Tribunal Supremo de 11 de junio de 1962 (RJ 1962\2903) afirmaba que "pese al escaso o nulo valor vinculativo que la furisprudencia asigna al precedente..., ha de discriminarse si los casos invocados son iguales o parecidos, de suerte que el diverso criterio de la Administración al resolverlos sea contrario a la doctrina de los actos propios o vulnere el principio de igualdad de los administrados ante la ley", y, aunque en este supuesto se desestimó el recurso, no ocurrió lo mismo en otros en los que la existencia de decisiones anteriores de la Administración -en sentido similar al pretendido por los recurrentes- permitió al Alto Tribunal estimar los correspondientes recursos en aplicación del principio de igualdad -sentencias del Tribunal Supremo de 14 de febrero de 1977 (RJ 1977\686), de 7 de mayo de 1979 (RJ 1979\2385), de 29 de octubre de 1979 (RJ 1979 \4269) y de 23 de diciembre de 1980 (RJ 1980\5130)-.

68 Señala el Tribunal Supremo al respecto en su sentencia de 11 de junio de 1982 (RJ 1982\2903) que "Ha de discriminarse si los casos invocados son iguales o parecidos"; para añadir la de 17 de abril de 1963 (RJ 1963\2261) que "no constan (en autos) los datos precisos para conocer si efectivamente se da o no la igualdad de circuns- 
permita una vulneración del precedente ${ }^{69}$, la limitación de la eficacia vinculante del precedente al ámbito de las potestades discrecionales, estando excluida su aplicación en el de las regladas ${ }^{70}$ y que el precedente sea ajustado a Derecho, lo

tancias y condiciones determinantes de la aplicabilidad del principio (de igualdad)"; para añadir la de 25 de abril de 1977 (RJ 1977\2647) que "con ello ya se vislumbra la no completa identidad objetiva entre un supuesto y los anteriores, con lo que, el motivo aducido resulta jurídicamente insuficiente para fundar la pretensión ejercitada"; y la de 7 de marzo de 1980 (RJ 1980\2101) que "hubiera sido necesario probar la existencia de unas legítimas autorizaciones municipales, en supuestos de hecho idénticos al del recurrente, y con respecto a normas de aplicación iguales". Sin embargo, como apunta SANTAMARÍA PASTOR (SANTAMARÍA PASTOR, Juan Alfonso y PAREJO ALFONSO, Luciano, Derecho Administrativo..., op. cit., pág. 112) "Es obligado reconocer, no obstante, que la jurisprudencia no es en este punto especialmente precisa: en unos casos se habla de identidad, en otros de semejanza; a veces se habla de identidad subjetiva y objetiva. En definitiva, la apreciación de la relación de semejanza -de identidad, en términos rigurosos, es imposible hablar- es un juicio que los Tribunales se reservan en cada caso concreto".

${ }^{69}$ Cuestión que no ha sido resuelta con claridad suficiente por la jurisprudencia del Tribunal Supremo, toda vez que, por una parte, en base al principio de igualdad, parece obligada la observancia del precedente cuando es legal y existe semejanza, pero, por otra, el artículo 54.1.c) de la Ley 30/1992, de 26 de noviembre, de Régimen Jurídico de las Administraciones Públicas y del Procedimiento Administrativo Común (RCL 1992\2512) -artículo 43.1.c) de la Ley de Procedimiento Administrativo de 17 de julio de 1958 (RCL 1958\1258)- parece habilitar a la Administración a desconocer el precedente, siempre y cuando se motive la decisión. Vid., sentencias, entre otras de 7 de mayo de 1979 (RJ 1979 2385 ), que señala que "sin que las razones que se alegan para fundamentar el acuerdo de reducción sean en absoluto convincentes, ya que no aparece como indudable la mejora para que para el interés público supondría la cesión...”; de 8 de mayo de 1979 (RJ 1979\2387); de 29 de octubre de 1979 (RJ 1979\4269); de 18 de marzo de 1981 (RJ 1981\1310).

${ }^{70}$ En sentencia del Tribunal Supremo de 30 de junio de 1978 (RJ 1978\3155) se afirma que el principio de igualdad "se proyecta con respecto a actos de contenido discrecional, pero en los reglados no pasa de ser un aspecto de la obligatoriedad común de la regla y por tanto su eficacia correctora se manifiesta sólo cuando el órgano que la aplica tiene posibilidad de opción, determinando la exigencia de igual interpretación para casos idénticos". En el mismo sentido, sentencias de 5 de diciembre de 1969 (RJ 1969\5655); de 8 de mayo de 1979 (RJ 1979\2387); de 27 de junio de 1979 (RJ 1979\2990); de 9 de febrero de 1980 (RJ 1980\649); de 12 de junio de 1980 (RJ 1980\3182). Aunque la sentencia del Alto Tribunal de 22 de marzo de 1976 (RJ 1976\2092) sí admite la aplicación de la doctrina tanto respecto de los actos discrecionales como de los reglados. Ver a este respecto también las sentencias del Tribunal Supremo de 21 de noviembre de 1977 (RJ 1977\4453); de 30 de junio de 1978 (RJ 1978\3155) y de 3 de abril de 1979 (RJ 1979\1562). No obstante "La discrepancia entre ambas líneas jurisprudenciales es sólo aparente: en realidad, la aplicación del par de conceptos potestades regladas-potestades discrecionales al tema que nos ocupa es dogmáticamente incorrecto y desorientador; el principio de igualdad opera respecto de la aplicación de todas las normas que ofrezcan un cierto margen interpretativo, lo cual ocurre prácticamente en todos los casos, tanto en el de las que atribuyen potestades discrecionales cuanto regladas. Si lo que ha querido decir el Tribunal Supremo es que la invocación del principio de igualdad es inútil en el caso de potestades absolutamente regladas, consistentes en la aplicación puramente mecánica y automática de normas que no admiten interpretaciones diversas, la conclusión es obvia. Y aún cabría señalar que la aplicación del principio de igualdad en la hipótesis de potestades discrecionales es, si cabe, menos justificada, habida cuenta de que la intención del legislador ha sido otorgar una libertad de decisión a la Administración y, por lo tanto, consagrar la posibilidad de soluciones diversas, dependientes sólo del libre arbitrio de los administradores. En todo caso, la introducción de este par de conceptos es innecesaria y perturbadora", SANTAMARÍA PASTOR, Juan Alfonso y PAREJO ALFONSO, Luciano, Derecho Administrativo..., op. cit., pág. 113.

Revista Andaluza de Administración Pública

ISSN: 0034-7639, núm. 82, Sevilla, enero-abril (2012), págs. 73-117 
que supone la prohibición de invocar, en base al principio de igualdad, precedentes ilegales ${ }^{71}$.

Por último, GARCÍA DE ENTERRÍA señala que "Cuando existe una Ley que ha de aplicarse, los sujetos se ordenan directamente a ella, sin tener que pasar por la versión que de la misma da uno de esos sujetos, la Administración; mucho más el argumento es aplicable respecto de los Tribunales, a los que sería absurdo entender vinculados por esa práctica administrativa. Dicho lo cual, conviene precisar inmediatamente que si no valor normativo estricto, el precedente reiterado puede tener un cierto valor vinculante para la propia Administración, en el sentido de que apartarse de él en un caso concreto puede ser índice de un trato discriminatorio, de una falta de buena fe, de una actitud arbitraria. Este juicio se explica fácilmente, sin necesidad de acudir a la tesis del precedente como costumbre, por virtud de los principios de la igualdad de los ciudadanos ante la Ley (art. 14 de la Constitución) y de la buena fe (en sus dos vertientes, de protección de la confianza del tercero, que ha podido orientar su actividad sobre el criterio mantenido hasta entonces por la Administración, y de interdicción de la arbitrariedad propia: artículos 7 CG y 9.3 de la Constitución). Los artículos 2 RSCL y 54.1.c) LPG justifican en nuestro Derecho ese tipo de vinculación al precedente; el primero concreta la obligación de ajustar la intervención administrativa en la actividad de los administrados al principio de igualdad ante la Ley; el segundo impone a la Administración la obligación de motivar los actos «que se separen del criterio seguido en actuaciones precedentes». En virtud del último precepto, resulta claro que la Administración puede eventualmente apartarse del precedente, pero tiene que explicitar las razones concretas que le llevan a ese apartamiento"72.

Establecidas pues, las diferencias entre costumbre y precedente administrativo, es evidente asimismo que la costumbre y las prácticas administrativas deben de considerarse realidades diversas, toda vez que la costumbre surge por el uso seguido en las relaciones entre particulares y las prácticas administrativas son "reglas deducidas del comportamiento de la Administración sin intervención del administrado"73. Pues bien, aun a pesar de que el papel de la costumbre como tal en Derecho Administrativo es evidentemente limitado, ello no comporta que sea nulo, toda vez que, aunque es complejo que surja en la relación jurídico-administrativa entre una Administración, que goza del poder jurídico de

\footnotetext{
${ }^{71}$ Cuestión ya examinada al analizar la costumbre contra legem o abrogatoria.

72 GARCÍA DE ENTERRÍA, Eduardo y FERNÁNDEZ RODRÍGUEZ, Tomás-Ramón, Curso de Derecho Administrativo..., op. cit., I, págs. 69 y 70.

${ }^{73}$ Voz costumbre, Enciclopedia furídica Básica, vol. II, op. cit., pág. 1772.
} 
decisión unilateral, y los administrados, no es imposible, a lo que se une que, en esas relaciones y en función de unas determinadas circunstancias el papel de la costumbre pueda desempeñarlo la práctica administrativa. Es el caso de la aplicación de las prácticas administrativas como fuente supletoria en el supuesto de ausencia de remisión legal expresa para cubrir las lagunas de la norma escrita ${ }^{74}$. Negado tradicionalmente el valor vinculante de la práctica administrativa en base a que no es costumbre, ya que le falta el elemento principal de la opinio iuris y los usos de la Administración no suelen devenir de una convicción jurídica, actualmente esos reparos carecen de apoyo, toda vez que el Código Civil, tras la reforma de 1973, establece que los usos jurídicos "tendrán la consideración de costumbre" (artículo 1.3.2 ${ }^{\circ}$ ), por lo que se le está otorgando a los usos o prácticas habituales idéntico valor normativo que a la propia costumbre.

\section{Supuestos de costumbre en Derecho Administrativo}

Admitido, pues que nuestro Derecho sólo admite la costumbre extra legem, como han señalado desde DE CASTRO hasta GARCÍA DE ENTERRÍA-, toca pues distinguir entre las dos modalidades apuntadas de costumbre extra legem, esto es, la costumbre extra legem que opera como fuente en virtud de remisión expresa por la ley escrita y la costumbre extra legem que opera como fuente supletoria en ausencia de remisión legal expresa. Finalmente, aunque ya se ha expresado su falta de viabilidad en Derecho Administrativo, se referirán algunos supuestos de costumbre contra legem.

A) Costumbre extra legem que opera como fuente en virtud de remisión expresa por la ley escrita

Señala GARRIDO FALLA que resulta muy difícil montar una teoría general de la costumbre como fuente del Derecho Administrativo, toda vez que pueden distinguirse dos grupos de costumbres en Derecho Administrativo: las costumbres que regulan el funcionamiento de instituciones administrativas que no han sido creadas por la ley sino que han surgido espontáneamente a lo largo de la historia, entre las que incluye los municipios que funcionan en régimen de Concejo Abierto y los Tribunales de Aguas; y las costumbres que regulan las relaciones entre particulares, aunque, por razón de la materia, tales relaciones se encuentran íntimamente conectadas con el interés público, entre las que incluye las relaciones de los usuarios de un aprovechamiento de aguas, de aprovechamientos forestales o comunales.

\footnotetext{
${ }^{74}$ Lo cual ha sido admitido por el Tribunal Supremo en sentencias, entre otras, de 3 de marzo de 1958 (RJ 1958\957) y de 15 de marzo de 1963 (RJ 1963\1676).
} 
La perspectiva histórica de la costumbre, esto es, su vigencia en relación con instituciones surgidas históricamente -aunque junto a planteamientos actuales-, es también apuntada por MORELL OCAÑA cuando afirma que "es preciso también levantar la vista sobre el puro presente y no marginar la dimensión histórica, la carga de historia que arrastran muchas de las instituciones jurídicas, públicas y privadas. En concreto, una vez que el Derecho público redefine su objeto y caben en su marco de observación una pluralidad de grupos portadores de una esfera de poder, unos fines colectivos y unas normas de ordenación y, por otra parte, se enriquece el enfoque introduciendo el transfondo histórico junto a los planteamientos exclusivamente actuales se puede ponderar debidamente la importancia de la costumbre, su fuerza organizatoria de la realidad jurídica y, especialmente, la jurídico-administrativa. La costumbre, es, pues, engendrada por la historia de determinados grupos sociales, y se mantiene allí donde esos grupos siguen teniendo una trascendencia como ámbito de ordenación de la convivencia. Y, en ese sentido, hay que señalar cómo una buena parte de las entidades que contempla el Derecho administrativo se sitúan en la actualidad con una vida histórica propia que éste no olvida sino que se ve obligado a ponderarla debidamente: las trata como seres que tienen una historia que hay que respetar, y de la que se desprenden unas reglas de ordenación que se han de incorporar al presente. Se comprende, entonces, que la norma consuetudinaria tenga su más amplio efecto organizatorio allí donde existen entidades con un largo pasado. En nuestro Derecho positivo, sobre todo las Entidades locales y las organizaciones de regantes". Pero, "Naturalmente, -continúa este autor-, la pura perduración de la norma, su largo pasado, es requisito necesario pero no suficiente para el reconocimiento del Derecho consuetudinario; junto a ello se sitúa, como otra exigencia, el origen extraestatal de la misma; esto es, que se trate de una norma que no ha nacido mediante una declaración de voluntad del correspondiente órgano del Estado" 75.

Ahora bien, lo trascendente es el poder aislar y distinguir las auténticas normas consuetudinarias en Derecho Administrativo, que surgen verdaderamente cuando el legislador se remite directamente a ellas considerándolas pura y simplemente como costumbre. Así puede encontrarse en la legislación administrativa de sectores concretos una expresa referencia a la costumbre, inclusive previa y prioritaria a la aplicación de la ley. No obstante, las presencia de la costumbre en los distintos sectores del Derecho Administrativo se hace presente de manera "asistemática y fragmentaria"76.

\footnotetext{
${ }^{75}$ MORELL OCAÑA, Luis, "La costumbre...", op. cit., págs. 26 y 27.

${ }^{76}$ MORELL OCAÑA, Luis, "La costumbre...", op. cit., pág. 25.
} 
Entre los supuestos reconocidos de costumbre en Derecho Administrativo y que encuentran cabida dentro de este primer grupo deben destacarse primeramente las Comunidades de Tierra o de Villa y Tierra, que, en base al artículo 17 de la Ley de Régimen Local, Texto Articulado y Refundido aprobado por Decreto de 24 de junio de 1955 (RCL 1956\74 y 101) van a continuar rigiéndose por sus normas consuetudinarias o tradicionales ${ }^{77}$. Por su parte, el artículo 101 del Reglamento de Organización, Funcionamiento y Régimen Jurídico de las Corporaciones Locales, aprobado por Decreto de 17 de mayo de 1952 (RCL 1952\1642) establecía que "Las Comunidades de Tierra, Villa y Tierra, pastos, leñas, aguas, universidades y a socios de cualquier indole, se regirán por sus normas consuetudinarias o tradicionales, con arreglo a lo dispuesto en el artículo 40 de la Ley (de Régimen Local)...".

\footnotetext{
${ }^{77}$ Las Comunidades de Villa y Tierra constituyeron una forma de organización política de la Extremadura castellana, las tierras conquistadas por el Reino de Castilla a Al-Ándalus entre los siglos XI y XII, y que se extendió también por algunas zonas del Bajo Aragón. Se trata de verdaderas repúblicas populares que dentro del reino de Castilla poseían los atributos de los estados autónomos de una federación, constituían los núcleos fundamentales de la estructura política y económica del estado castellano. Las Comunidades no eran, pues, mancomunidades o asociaciones más o menos transitorias o circunstanciales de Municipios, como a veces se afirma, sino los núcleos políticos y económicos fundamentales de la vieja Castilla por encima de los cuales, en un escalonamiento de jurisdicciones y poderes, estaba la Corona y por debajo quedaban los Municipios. Las Comunidades de Villa y Tierra consisten en la existencia de tierras comunadas que incluían a distintas aldeas alrededor de una Villa mayor y que se subdividían, a su vez, en seis sexmas u ocho ochavos. Estas tierras podían ser, según su dueño, de realengo si son del Rey, de abadengo si son de un abad o de un obispo, de solariego si son de un noble u orden militar o de behetría si son los propios habitantes quienes eligen al señor. En este nuevo sistema, el centro y eje del esquema administrativo será la Villa. Los vecinos o villanos, organizados en concejo, reciben del Rey un amplio territorio de centenares y aún millares de kilómetros cuadrados, sobre el que van a ejercer los derechos de propiedad y organización que anteriormente correspondían al Rey, magnates y abades. Las competencias del concejo eran: dirigir el nacimiento e instalación de las aldeas en su territorio, repartir las heredades entre los vecinos y reservar otras tierras para aprovechamiento concejil y comunal; y establecer las normas que regulan las relaciones entre la propia aldea y otras, así como entre los vecinos de unas y otras. Las normas venían reguladas por los Fueros, sancionados por el monarca. La Villa dependía únicamente del Rey, elegía anualmente, vecinalmente o por parroquias, a sus propias autoridades, con una duración de los cargos de un año, y estos ejercían todas las competencias gubernativas, judiciales, económicas e incluso militares. Las competencias de la Comunidad y su autonomía no estaban reñidas con la presencia en la misma de un representante del Rey para velar por sus intereses, especialmente fiscales. Todas las Comunidades eran iguales y sólo se relacionaban directamente con el Rey, siendo éste el único lazo de unión con la Corona. Así se pueblan y organizan las tierras al sur del río Duero, en cuarenta y dos Comunidades, que integrarían la denominada Extremadura castellana. Este régimen de libertades y autonomía será considerado como una situación de privilegio por las poblaciones más antiguas de Castilla. Por otra parte, al norte del río Duero, el proceso de señorización englobaba en el siglo XIII a la mitad de sus aldeas, en las Comunidades de Villa y Tierra el avance señorial es frenado casi totalmente por la mayor capacidad de resistencia de éstas, que sólo comenzará a romperse en la segunda mitad del siglo en las Comunidades de menor extensión. En relación a estas Comunidades, vid., CARRETERO Y JIMÉNEZ, Anselmo, "Comunidad de villa y tierra, núcleo básico de la federación medieval castellana", La personalidad histórica de Castilla en el conjunto de los pueblos hispánicos, Hyspamérica de Ediciones, San Sebastián, 1977, págs. 49 a 64.
} 
Otra institución surgida históricamente que es obligado mencionar cuando se hace referencia a la costumbre en Derecho Administrativo es la de los $\mathrm{Mu}-$ nicipios que funcionan en régimen de Concejo Abierto. El Estatuto Municipal de 8 de marzo de $1924^{78}$ restableció el régimen de Concejo Abierto en el caso de determinados Municipios, concretamente señalaba su artículo 42 que "En los Municipios que no excedan de 500 habitantes serán Concejales todos los electores, en Concejo abierto. En los de más de 500 a 1.000 habitantes serán Concejales, cada tres años, la mitad de los electores no incapacitados para el cargo, a cuyo efecto se dividirá la lista alfabética de electores constitutiva del Censo, en cuatro partes iguales, por riguroso y sucesivo orden de apellidos a partir de la letra A. El primer turno trienal se formará con los dos primeros grupos de electores, y al concluir el trienio se fijará por sorteo la mitad que ha de ser sustituida por el tercer grupo. Concluido el segundo trienio, entrará el último grupo a sustituir al que hubiese formado parte del Ayuntamiento durante seis años consecutivos". Por su parte, el Reglamento de Organización, Funcionamiento y Régimen Jurídico de las Corporaciones Locales de 1952 señalaba en el supuesto del Municipio que "los antiguos usos, costumbres u ordenanzas locales o comarcales que comporten modalidades típicas de cualquier indole, avaladas por la tradición o por la historia, podrán ser declaradas subsistentes en su primitiva forma o adaptadas a las transformaciones de la vida comunal" por la Administración del Estado, tras una valoración desde el punto de vista del interés o el orden público o la inconciliabilidad con las leyes (artículos 111 y 112), por lo que la subsistencia de la costumbre es cuestión que se deja a la intervención estatal. Según el artículo 111.1 del Reglamento de Organización, Funcionamiento y Régimen Jurídico de las Entidades Locales aprobado por Real Decreto 2568/1986, de 28 de noviembre de 1986 (RCL 1986\3812) el funcionamiento de las Asambleas Vecinales en el régimen de Concejo Abierto "se ajustará a los usos, costumbres y tradiciones locales y, en su defecto, a la Ley 7/1985, de 2 de abril, y a las leyes de las Comunidades Autónomas sobre Régimen Local. En defecto de estas últimas se aplicará el presente artículo y, en lo posible, lo establecido en el Capitulo Primero de este Título", por lo que, más rotundamente que en la normativa precedente, se sitúan la Ley de Bases de Régimen Local y las leyes autonómicas en la materia como Derecho supletorio de la costumbre, y es que el artículo 218 del Reglamento de Organización, Funcionamiento y Régimen Jurídico de las Corporaciones Locales de 1952 refería respecto a las Juntas Vecinales de las Entidades Locales Menores que "el funcionamiento de tales organismos se regirá por sus observaciones u Ordenanzas locales, y en lo que no sea especifico ni se oponga a los usos, costumbres o tradiciones, por los preceptos aplicables de la Ley y de este Reglamento", esto es, la ley se coloca claramente como Derecho supletorio. Continúa diciendo el artículo 111 del Reglamento de Organización, Funcionamiento y Régimen Jurídico de las

${ }^{78}$ Gaceta de Madrid núm. 69, de 9 de marzo de 1924. 
Entidades Locales de 1986 que "2. Las Asambleas vecinales se reunirán donde lo tengan por costumbre, celebrarán sesión ordinaria como mínimo una vez al trimestre en día festivo, y serán convocadas a toque de campana, por pregón, por anuncio o por cualquier otro medio de uso tradicional en el lugar. 3. Para que dichas Asambleas queden válidamente constituidas habrá de asistir una tercera parte de los vecinos, presentes o representados, que a ello tengan derecho. En ningún caso el número de presentes podrá ser inferior a tres. Se requiere siempre la presencia del Presidente y del Secretario o de quienes legalmente les sustituyan. La representación de los vecinos podrá otorgarse para cada sesión o con carácter permanente pero siempre en favor de vecino perteneciente a la Asamblea vecinal. La representación deberá acreditarse mediante documento público, documento privado con firma notarialmente legitimada o poder otorgado ante el Secretario de la entidad local. Ningún vecino podrá asumir la representación de más de un tercio de los miembros de la Asamblea vecinal. 4. Los acuerdos se adoptarán por mayoría de votos". Por su parte, dispone el artículo 29 de la Ley 7/1985, de 2 de abril, de Bases de Régimen Local (RCL 1985\799), modificado por la Disposición Final 1.1 de Ley Orgánica 2/2011, de 28 de enero (RCL $2011 \backslash 136)$, que modifica el régimen electoral general, que "3. En el régimen de Concejo Abierto, el gobierno y la administración municipales corresponden a un Alcalde y una asamblea vecinal de la que forman parte todos los electores. Ajustan su funcionamiento a los usos, costumbres y tradiciones locales y, en su defecto, a lo establecido en esta Ley y las leyes de las Comunidades Autónomas sobre régimen local ${ }^{, 79}$.Y el artículo 53 del Real Decreto Legislativo 781/1986, de 18 de abril, por el que se aprueba el Texto Refundido de las disposiciones legales vigentes en materia de Régimen Local (RCL 1986\1238) señala que "Las Funtas o Asambleas vecinales de las Entidades locales de ámbito territorial inferior al municipal ajustarán, también, su funcionamiento a lo dispuesto en los artículos anteriores, que se aplicarán, asimismo, para las Asambleas vecinales en el régimen de Concejo abierto en todo aquello que no sea especifico de este régimen ni se oponga a los usos, costumbres o tradiciones locales. Los acuerdos se adoptarán siempre por mayoría de votos", esto es, ajusta su funcionamiento a los usos, costumbres o tradi-

${ }^{79}$ Establece el artículo 29 que "1. Funcionan en Concejo Abierto: a) Los municipios que tradicional y voluntariamente cuenten con ese singular régimen de gobierno y administración. b) Aquellos otros en los que por su localización geográfica, la mejor gestión de los intereses municipales u otras circunstancias lo hagan aconsejable. 2. La constitución en concejo abierto de los municipios a que se refiere el apartado b) del número anterior, requiere petición de la mayoría de los vecinos, decisión favorable por mayoría de dos tercios de los miembros del Ayuntamiento y aprobación por la Comunidad Autónoma. 3. En el régimen de Concejo Abierto, el gobierno y la administración municipales corresponden a un Alcalde y una asamblea vecinal de la que forman parte todos los electores. Ajustan su funcionamiento a los usos, costumbres y tradiciones locales y, en su defecto, a lo establecido en esta Ley y las leyes de las Comunidades Autónomas sobre régimen local. 4. No obstante lo anterior, los alcaldes de las corporaciones de municipios de menos de 100 residentes podrán convocar a sus vecinos a Concejo Abierto para decisiones de especial trascendencia para el municipio. Si así lo hicieren deberán someterse obligatoriamente al criterio de la Asamblea vecinal constituida al efecto. Los municipios que con anterioridad venían obligados por Ley en función del número de residentes a funcionar en Concejo Abierto, podrán continuar con ese régimen especial de gobierno y administración si tras la sesión constitutiva de la Corporación, convocada la Asamblea Vecinal, así lo acordaran por unanimidad los tres miembros electos y la mayoría de los vecinos".

Revista Andaluza de Administración Pública

ISSN: 0034-7639, núm. 82, Sevilla, enero-abril (2012), págs. 73-117 
ciones locales. En los artículos 29 de la Ley de Bases de Régimen Local y 53 del Texto Refundido de Régimen Local se observa, pues, la preferencia de la costumbre sobre lo establecido con carácter general respecto a los Municipios tanto en dichas normas como en las normas autonómicas de régimen local.

En otro orden de cosas, concretamente entre las llamadas propiedades especiales, debe hacerse mención al Tribunal de las Aguas de Valencia, que constituye sin duda una de las más antiguas instituciones de justicia existentes en Europa, se reúne semanalmente, todos los jueves del año a medio día, en el lado derecho de la gótica Puerta de los Apóstoles de la Catedral de Valencia. El Tribunal tiene una doble función: judicial y administrativa ${ }^{80}$. Por costumbre, se utiliza el nombre de Tribunal de los Acequieros de la Vega de Valencia para referirse a estas

${ }^{80}$ El funcionamiento del Tribunal de las Aguas de Valencia es sumamente sencillo. La persona denunciada es citada por el Guarda de la Acequia para el jueves siguiente. Hasta dos veces más es citado y, si no acude tampoco a la tercera citación, tras admitirse la denuncia, se le juzga en rebeldía pudiendo ser condenado. Nunca ha sido necesario acudir a la fuerza pública para hacerle comparecer. Se sientan los síndicos en los sillones asignados a cada una de sus respectivas Acequias. Asiste el Alguacil del Tribunal, antaño guarda mayor o verdadero "atandador", encargado de dar el agua y levantar las compuertas o paradas, portador, como insignia, de un impropio arpón de latón dorado, de dos púas, una de ellas encorvada, que era el instrumento con que separaban y recogían las tablas de las ranuras de los partidores. El Alguacil, solicita del Presidente la venia para iniciar las citaciones y llama públicamente: "iDenunciats de la Séquia de Quart!', y acuden los denunciados, si los hay, acompañados por el Guarda de la Acequia. Las citaciones se van haciendo por el orden en que las Acequias toman el agua del río, iniciándose por la de Quart, que es la primera, y terminando por la de Robella, que es la última. El Guarda expone el caso o presenta al querellante, si hay acusador privado. Acaba con la frase de ritual: "Es quant tenia que dir". El Presidente inquiere: "qué té que dir l'acusat?", y pasa a defenderse el acusado. Ya ha caído en desuso el célebre "calle vosté i parle vosté", al igual que aquella antigua costumbre, de tradición árabe, de señalar con el pie a quien se concedía la palabra. Los trámites son totalmente verbales. El desarrollo del juicio enteramente en lengua valenciana. Todos intervienen en su propio nombre, ni abogados ni documentos escritos; pueden proponer testigos e incluso inspección ocular (la 'visura'). El Presidente y los miembros del Tribunal pueden hacerle las preguntas necesarias para mejor información del caso y, sin más trámite y en presencia de los interesados, el Tribunal delibera y sentencia. Para garantizar la imparcialidad, en la deliberación no interviene el Síndico de la Acequia a la que pertenecen los litigantes; y, también es norma que, si el denunciado pertenece a una Acequia de la derecha del río, la sentencia la propongan los síndicos de las Acequias de la izquierda, y viceversa. Si la sentencia es condenatoria, el Presidente lo hace con la frase de ritual: "Este Tribunal li condena a pena i costes, danys i perjuins, en arreglo a Ordenances". Las Ordenanzas de las respectivas Acequias establecen las penas para las distintas infracciones. Y no caben recursos ni apelaciones ya que la sentencia es ejecutiva de por sí; de ello se encarga el Síndico de la Acequia. El Tribunal sólo reconoce y sentencia si el denunciado es culpable o inocente. De esta forma tan simple y sencilla, al tiempo que tan efectiva y respetada por todos los miembros de una comunidad agrícola, ha solucionado sus problemas de aguas el laborioso pueblo valenciano desde los tiempos más remotos. No hay abogados, no hay documentos, no hay largísimos trámites burocráticos que retrasen lo que constituye el más elemental de los derechos humanos, la justicia. En cuanto al motivo de las denuncias se trata, sobre todo, de hurto de agua en tiempos de escasez, rotura de canales o muros, 'sorregar' echando agua en campos vecinos que dañan la cosecha por exceso de ésta, alterar los turnos de riego tomando el agua el día que no procede, tener las Acequias sucias que impidan que el agua circule con regularidad, levantar la 'parada' cuando un 
dos funciones, conjuntamente, mientras que el nombre de Tribunal de las Aguas se reserva para las funciones judiciales propiamente dichas. En realidad son dos órganos distintos pero que actúan el mismo día, lugar y hora. Se regula únicamente en el Decreto de 5 de abril de 1932, que reconoce su existencia y confirma sus privilegios de los siglos XIII y XIV y su autonomía de jurisdicción. Se compone de 8 síndicos-jueces, correspondientes a las acequias y comunidades de regantes de la Vega de Valencia. Cuando ejercen funciones administrativas son denominados síndicos, cuando jurisdiccionales jueces. Son elegidos democráticamente en cada comunidad de regantes, de acuerdo con las ordenanzas respectivas de cada acequia, debiendo ser labradores, propietarios y cultivadores directos de las tierras regadas por la acequia, siendo elegidos como regla general por un período de hasta 3 años, con posibilidad de reelección. Este Tribunal está reconocido como Tribunal consuetudinario y tradicional en la Ley Orgánica 6/1985, de 1 de julio, del Poder Judicial (RCL 1985\1578), concretamente su artículo 19.3 dispone que: "Tiene el carácter de Tribunal consuetudinario y tradicional el Tribunal de las Aguas de la Vega Valenciana". Asimismo debe referirse aquí el Consejo

regante está usando de su turno, regar sin solicitud de turno, etc. Pueden, asimismo ser juzgados los empleados de las Acequias, tanto por su condición de regantes como por su actuación ante otras Comunidades de Regantes. Incluso los propios Síndicos, como ya se ha comentado. La jurisdicción se extiende, asimismo, a personas ajenas a las Comunidades de Regantes que han causado algún perjuicio al sistema de riegos, pues, con sus actos, han entrado por propia decisión en la esfera de competencias del Tribunal. En caso de no comparecencia, se les puede condenar igualmente, y se puede acudir después a la vía ordinaria presentando la correspondiente demanda civil por los daños y perjuicios causados, aduciendo entre las pruebas la sentencia condenatoria del Tribunal de las Aguas. Los trámites del juicio, como ya se ha dicho, son totalmente verbales. No obstante, tras la primera Ley de Aguas, la necesidad de dejar una cierta constancia, condujo a un Libro Registro en el que figuran unos pocos datos de cada juicio, tales como: Acequia donde se produjo el hecho, nombre de denunciado y denunciante, motivo de la denuncia, fallo y fecha. El Tribunal tiene una doble función: judicial y administrativa. Por costumbre, se utiliza el nombre de Tribunal de los Acequieros de la Vega de Valencia para referirse a estas dos funciones, conjuntamente, mientras que el nombre de Tribunal de las Aguas se reserva para las funciones judiciales propiamente dichas. En realidad son dos órganos distintos pero que actúan el mismo día, lugar y hora, e integrados por las mismas personas (el Síndico es, a la vez, jurado y acequiero) o con una ligera variación: la Acequia de Robella tiene un Síndico-jurado y un Síndico-acequiero, y la Acequia de Chirivella no tiene Síndico-jurado. Cuando acaban de ser juzgados los casos denunciados en el marco de la Puerta de los Apóstoles, los síndicos pasan a la vecina Casa-Vestuario para tratar los asuntos comunes; en este caso son nueve los síndicos puesto que se incorpora el representante de Chirivella. El problema fundamental a tratar es la situación del agua del río; según el caudal, se decide abrir más o menos los tornos de las Acequias y, si procede, solicitar, acudiendo a antiguos privilegios concedidos por el rey Jaime II, en 1321, agua de la Acequia de Moncada (la antigua acequia Real o de Puzol). En este aspecto administrativo, el Tribunal está sujeto al Comisario de Aguas, como entidad superior, que tendrá que resolver las cuestiones planteadas entre el Tribunal de las Aguas y el Acequiero mayor de Moncada. Actualmente, el tema principal de las reuniones está en relación con la salida de agua del Pantano de Benagéber. La función jurisdiccional es competencia exclusiva del Tribunal; en su función administrativa se ve éste auxiliado por los letrados de todas las Comunidades, que aconsejan sobre ordenanzas, intervienen ante la jurisdicción ordinaria, presentan los recursos en defensa de la Huerta, etc. 
de Hombres Buenos de la Huerta de Murcia es un Tribunal consuetudinario y tradicional, tal y como se establece en el artículo 19.4 de la Ley Orgánica del Poder Judicial $^{81}$, por lo que sus reglas y autoridad vienen dadas por la tradición y la costumbre, siendo depositario, al igual que el Tribunal de las Aguas de Valencia, de una milenaria cultura solidaria y democrática del agua, cuya misión es garantizar el buen funcionamiento de las extensas y complejas redes de canales de riego comunales que configuran el paisaje cultural agrícola de las riberas de los ríos Segura y Turia en torno a la ciudad de Murcia, estando encargado de dirimir los conflictos de riego en la Huerta de Murcia. Hasta su reconocimiento como órgano jurisdiccional especial por la Ley Orgánica 13/1999, de 14 de mayo, de modificación de la Ley Orgánica del Poder Judicial (RCL 1999\1305) era indiscutible que se trataba de un organismo administrativo. Su origen se encuentra en la época de dominación árabe, estando documentado el Sobrecequiero o Magistrado de la Huerta desde 1614, su antecedente, y regulado básicamente el Consejo por las Ordenanzas de la Huerta de Murcia ${ }^{82}$, que organizan los riegos de la Vega de Murcia y las relaciones de la comunidad de regantes. La Ley de Aguas y el Código Civil son normas supletorias de las mismas. El Consejo de Hombres Buenos conoce de todas las controversias que se susciten entre regantes, de las reclamaciones sobre los perjuicios que se causen a terceros y de los abusos e infracciones a las Ordenanzas, estando presidido por el Alcalde del Ayuntamiento en donde se celebre la audiencia pública, aunque sólo vota en caso de empate. Sus fallos se dictan de plano y por mayoría absoluta, una vez han sido oídas las partes y practicadas las correspondientes pruebas. El Alcalde es la autoridad de ejecución, y quien resuelve el recurso de nulidad o de injusticia notoria contra la resolución, en caso de que se interponga, razones por las que, a pesar de la Ley Orgánica 13/1999, de 14 de mayo, de modificación de la Ley Orgánica del Poder Judicial, seguimos pensando que estamos ante un órgano de naturaleza claramente administrativa. En 2009 ambos, Tribunal de las Aguas de Valencia y Consejo de Hombres Buenos de la Huerta de Murcia, son designados Patrimonio Cultural Inmaterial de la Humanidad por la UNESCO por ser testimonio único de una tradición cultural viva, la de la justicia y el gobierno democrático y autogestionario de las aguas por parte de los campesinos andalusíes en el ámbito de las huertas que rodeaban las grandes ciudades de la fachada mediterránea de la Península Ibérica ${ }^{83}$.

${ }^{81}$ Apartado añadido por el artículo 1 de Ley Orgánica 13/1999, de 14 de mayo, de modificación de la Ley Orgánica del Poder Judicial (RCL1999\1305).

82 Del año 1849, compuestas por 178 artículos.

83 Sobre el Tribunal de las Aguas de Valencia, vid., BORRULL Y VILANOVA, Francisco Xavier, Discurso sobre la distribución de las aguas del Turia y deber conservarse el Tribunal de los acequieros de Valencia, Imprenta de D. Benito Monfort, Valencia, 1928; GUILLÉN RODRÍGUEZ DE CEPEDA, Antonio, El Tribunal de las Aguas de Valencia. Los modernos Jurados de riego: tesis doctoral, Est. Tipográfico Doménech, Valencia, 1920; GINER BOIRA, Vicente, El Tribunal de las Aguas de la Vega de Valencia, Ed. Giner Boira, Valencia, 1953. 
Abundando en lo que acaba de decirse, el artículo 77 in fine, de la Ley 29/1985, de 2 de agosto, de Aguas (RCL 1985\1981), dispone que "alli donde existan Furados o Tribunales de riego, cualquiera que sea su denominación peculiar, continuarán con su organización tradicional", por lo que se corrobora el papel fundamental de la costumbre ${ }^{84}$.

Por su parte, ya aludía también a la costumbre la Ley de Aguas de 13 de junio de $1879^{85}$ que disponía en su artículo 234 que "En los regadios hoy existentes y regidos por reglas, ya escritas, y a consuetudinarias, de una comunidad de regantes, ninguno será perjudicado ni menoscabado en el disfrute del agua de su dotación y uso, por la introducción de cualquier novedad en la cantidad, aprovechamiento o distribución de las aguas en el término regable", añadiendo su artículo 237 que "El reglamento para el Sindicato lo formará la Comunidad. Serán atribuciones del Sindicato: $2^{a}$. Dictar las disposiciones convenientes para la mejor distribución de las aguas, respetando los derechos adquiridos y las costumbres locales". Finalmente, debe hacerse mención al artículo 247 de este texto legal que señalaba que "Donde existan de antiguo Furados de riego, continuarán con su actual organización, mientras las respectivas comunidades no acuerden proponer su reforma al Ministerio de Fomento", por lo que, la costumbre conserva toda su eficacia organizatoria en tanto en cuanto no sea objeto de reforma por voluntad de la Comunidad.

En materia de bienes comunales debe hacerse mención en primer lugar a la Ley de Defensa de bosques de 24 de julio de $1918^{86}$ y su Reglamento de aplicación de 5 de septiembre de $1918^{87}$, que se refieren a la costumbre del lugar y de la comarca en materia de aprovechamientos forestales. El Real Decreto núm. 1042, de 8 de abril de 1930 (RCL 1930\618) (88 $^{8}$, sobre ordenación y disfrute de aprovechamientos de los bienes comunales, afirma respecto a estos que "siempre que no se encuentren en oposición con lo que, en orden a los mismos, pueda existir para ellos con carácter tradicional, en cuyo caso continuarán vigentes para regularlos las costumbres del país". Posteriormente la legislación de Régimen Local de 1955 otorgó primacía a la costumbre en lo referente a la ordenación del disfrute general y simultáneo de dichos bienes por el común de los vecinos, concretamente el artículo 192.2 de la Ley de Régimen Local de 1955 establecía que "Cuando el

\footnotetext{
${ }^{84}$ Otro Tribunal consuetudinario de características semejantes al de las Aguas de Valencia y al Consejo de Hombres Buenos de la Huerta Murciana es el Lligalló de Morella, sobre él, vid., VALLS TABERNER, Fernando, El Tribunal de Lligalló de Morella, Imp. V. Carceller, Morella, 1926.

${ }^{85}$ Gaceta de Madrid núm. 170, de 19 de junio de 1879.

${ }^{86}$ Gaceta de Madrid núm. 213, de 28 de julio de 1918.

${ }^{87}$ Gaceta de Madrid núm. 255, de 8 de septiembre de 1918.

${ }^{88}$ Gaceta de Madrid núm. 99, de 9 de abril de 1930.
} 
disfrute general y simultaneo de los bienes comunales fuera impracticable a falta de costumbre o reglamentación local, se adjudicará su aprovechamiento...". Como señala ALEJANDRO NIETO, el supuesto presenta cierta complejidad ${ }^{89}$, lo cual ha sido igualmente apuntado MORELL OCAÑA ${ }^{90}$. Y es que, como puso de relieve el Consejo de Estado en su Dictamen de 7 de octubre de $1956^{91}$, las ordenanzas, no obstante su carácter, atribuido por la ley, de sistematizadoras de normas consuetudinarias tradicionalmente observadas, no se conciben limitadas en sí mismas, esto es, petrificadas e inalterables (lo cual fue asimismo señalado por las sentencias del Tribunal Supremo de 6 de diciembre de 1962 y 31 de enero y 26 de diciembre de 1963), sino que, por el contrario, "podrán ser adaptadas a las transformaciones de la vida comunal". Por su parte, las sentencias del Tribunal Supremo de 28 y 31 de enero de 1963 afirman que "La frase "normas consuetudinarias tradicionalmente observadas" del artículo único de la Ley de 23 de diciembre de 1848 es la condición o premisa necesaria para que determinados Ayuntamientos-aquellos en los cuales existieran consuetudinariamente montes comunales con aprovechamientos en los que se concedieran a los vecinos suertes o cortas de madera, lo que desde tiempo inmemorial venía sucediendo en Covaleda- pudieran ejercitar en esta materia su potestad reglamentaria". También es de destacar el Dictamen del Consejo de Estado de 14 de mayo de $1969^{92}$, que contempla un supuesto de aprovechamientos comunales en el que el Ayuntamiento decide que se sigan realizando según costumbre, aunque no acredita la imposibilidad de la realización del aprovechamiento de acuerdo con otras formas a la que la ley otorga primacía. Se admiten, pues, ambas posibilidades. En determinados casos de montes con aprovechamientos madereros la costumbre local vincula la participación de únicamente los vecinos que reúnan "determinadas condiciones de vinculación, arraigo, permanencia o edad" (el artículo 192.4 de la Ley de Régimen Local de 1955 disponía que "Los Ayuntamientos y Juntas vecinales que viniesen ordenando el disfrute y aprovechamiento de montes comunales mediante concesiones periódicas a los vecinos de suertes o cortas de madera, de acuerdo con normas consuetudinarias o reglamentaciones locales tradicionalmente observadas..."), quedando el Ayuntamiento condicionado por el respeto a la costumbre cuando pretende ejercitar su potestad normativa para la determinación de los titulares de estos aprovechamientos. Se trata de un caso de primacía de la costumbre en el ordenamiento jurídico propio de estas entidades municipales ${ }^{93}$.

${ }^{89}$ NIETO GARCÍA, Alejandro, Bienes comunales, Ed. Revista de Derecho Privado, Madrid, 1964, pág. 215.

${ }^{90}$ MORELL OCAÑA, Luis, "La costumbre...", op. cit., pág. 30.

${ }^{91}$ Recopilación de Doctrina Legal, 1965-66, Madrid, pág. 6051.

${ }^{92}$ Recopilación de Doctrina Legal, 1968-69, Madrid, pág. 503.

${ }^{93}$ En este sentido, vid., el Dictamen del Consejo de Estado de 19 de octubre de 1967 (Recopilación de Doctrina Legal, 1967-68, Madrid, págs. 608 y 609), en el que el Consejo considera que la ordenanza no debe aprobarse porque modifica (ampliándolos) los derechos consuetudinariamente adquiridos por los veci- 
El artículo 75.2 del Texto Refundido de Régimen Local de 1986, al referirse al aprovechamiento y disfrute de los bienes comunales por la colectividad dispone que "Cuando este aprovechamiento y disfrute general simultáneo de bienes comunales fuere impracticable, regirá la costumbre u ordenanza local, al respecto y, en su defecto, se efectuarán adjudicaciones de lotes o suertes a los vecinos, en proporción directa al número de familiares a su cargo e inversa a su situación económica", mientras que el número 4 del mentado artículo y en el mismo sentido el artículo 103.2 del Real Decreto 1372/1986, de 13 de junio, por el que se aprueba el Reglamento de Bienes de las Entidades Locales (RCL 1986\2217) ${ }^{94}$ establece que "Los Ayuntamientos y Juntas vecinales que, de acuerdo con normas consuetudinarias u Ordenanzas locales tradicionalmente observadas, viniesen ordenando el disfrute y aprovechamiento de bienes comunales, mediante concesiones periódicas de suertes o cortas de madera a los vecinos, podrán exigir a éstos, como condición previa para participar en los aprovechamientos forestales indicados, determinadas condiciones de vinculación y arraigo o de permanencia, según costumbre local, siempre que tales condiciones y la cuantía máxima de las suertes o lotes sean fijadas en ordenanzas especiales, probadas por el órgano competente de la Comunidad Autónoma, previo dictamen del órgano consultivo superior del Consejo de Gobierno de aquélla, si existiere, o, en otro caso, del Consejo de Estado", vemos pues cómo este texto se remite expresamente a las normas consuetudinarias u ordenanzas locales tradicionalmente observadas. La sentencia del Tribunal Supremo de 4 de diciembre de 2007, Sala de lo Contencioso-Administrativo, Sección 4 $4^{\mathrm{a}}$ (RJ 2007\8972) es suficientemente expresiva a este respecto en tanto en cuanto considera que la exigencia establecida de ser natural del municipio para ser beneficiario del disfrute y aprovechamiento de los bienes comunales resulta conforme con la vinculación, arraigo y permanencia a que se refieren el Real Decreto 781/1983,

nos; así como el Dictamen del mismo Consejo de 17 de diciembre de 1970 (Recopilación de Doctrina Legal, 1970-71, Madrid, págs. 191 a 193), en el que afirma que "el supuesto del articulo 192-4 de la Ley de Régimen Local, de aprobación de Ordenanzas con exigencia de determinadas vinculaciones de arraigo, permanencia o edad para el disfrute de bienes comunales, es el de «los Ayuntamientos o funtas Vecinales que viniesen ordenando el disfrute y aprovechamiento de montes comunales mediante concesiones periódicas de suertes o cortas de madera, de acuerdo con normas consuetudinarias o reglamentaciones locales tradicionalmente observadas. Es decir, que se requiere que exista un régimen tradicional, consuetudinario, y la conservación de él es el objetivo de dicho precepto (...) No ocurre así en el presente caso (...), en consecuencia, no se trata de recoger en norma expresa el contenido anterior de un régimen consuetudinario, sino de crear esa norma ex novo, lo que, evidentemente, no encaja en el mentado supuesto legal".

94 Expresa el mencionado precepto que: "Los ayuntamientos y juntas vecinales que viniesen ordenando el disfrute y aprovechamiento de bienes comunales, mediante concesiones periódicas a los vecinos de suertes o cortas de madera, de acuerdo con normas consuetudinarias u ordenanzas locales tradicionalmente observadas, podrán exigir a aquellos, como condición previa para participar en los aprovechamientos forestales indicados, determinadas condiciones de vinculación y arraigo o de permanencia, según costumbre local, siempre que estas condiciones singulares y la cuantía máxima de las suertes o lotes sean fijadas en ordenanzas especiales, que necesitaran para su puesta en vigor la aprobación del órgano competente de la Comunidad Autónoma, el cual la otorgará o denegará, oído el Consejo de Estado o el órgano consultivo superior del Consejo de Gobierno de aquella, si existiera". 
de 18 de abril y el Reglamento de Bienes de las Entidades Locales, y por ello determina la conformidad a Derecho de la Ordenanza reguladora de los aprovechamientos forestales, pastos y caza de las fincas comunales: la vinculación, el arraigo y la permanencia son exigencias perfectamente lícitas y ninguna lo es más en el sentido de la norma cuando menciona la vinculación, que la relativa al nacimiento en el lugar, a la que se yuxtaponen por lo que se refiere al arraigo o permanencia la vecindad y la residencia continuada. En su conjunto, y sin que se pueda prescindir de ninguna, garantizan la permanencia de los bienes en el común, y que los beneficios que los mismos producen repercutan de modo directo en quienes permanecen en el Municipio. Y en lo que aquí interesa, toda la normativa referida en la sentencia transcrita es el producto de una larga evolución del Derecho a lo largo de un dilatado período de tiempo que viene a reconocer la convivencia de las costumbres locales con la ordenación positiva de los aprovechamientos de bienes comunales de los Ayuntamientos y Entidades Locales menores, y que admite la prevalencia de la costumbre cuando la misma se recoge en Ordenanzas Locales dictadas específicamente para esos aprovechamientos y aprobadas con la condiciones que imponen las normas que se ocupan de la cuestión ${ }^{95}$.

\footnotetext{
${ }^{95}$ Haciendo una sinopsis de la mentada sentencia del Tribunal Supremo de 4 de diciembre de 2007, el recurso de casación interesa la revocación de la sentencia dictada por la Sala de lo Contencioso-Administrativo del TSJ de Castilla y León, de 16 de enero de 2004 que declaraba que no podría adicionarse por Ordenanza municipal la exigencia de ser natural del municipio al bastar la residencia real y efectiva, como el arraigo en el mismo, para ser considerado vecino a efectos del derecho al disfrute del aprovechamiento. Concretamente se formulan dos motivos de casación: El primero de ellos invoca la infracción por inaplicación del art. 75.4 del TRRL, Real Decreto Legislativo 781/1986, y del art. 103.2 del Reglamento de Bienes de las Corporaciones Locales, Real Decreto 1372/1986. El segundo denuncia infracción de la jurisprudencia recaída sobre dichos preceptos y cita las Sentencias de 11 y 24 de abril de 2000, así como la de 25 de octubre de 1995 y otras anteriores que avalan su postura. Aquellas normas son producto de una dilatada evolución del Derecho que viene a reconocer la convivencia de las costumbres locales con la ordenación positiva de los aprovechamientos de bienes comunales de los Ayuntamientos y Entidades Locales menores, y que admite la prevalencia de la costumbre cuando se recoge en Ordenanzas Locales dictadas ad hoc para esos aprovechamientos y aprobadas con la condiciones que imponen las normas que se ocupan de la cuestión. En relación con el valor de la costumbre incorporada a las Ordenanzas locales, en Sentencia de 21 de febrero de 2007, la Sala ya consideró en relación con los bienes comunales y con su aprovechamiento y disfrute que, si fuere impracticable, regirá la costumbre u Ordenanza local, en base a lo dispuesto por el art. 75.2 y 4 del TRRL y artículo 95 del Reglamento de Bienes, es decir que la costumbre está presente en nuestro ordenamiento y en concreto cuando de aprovechamiento de bienes comunales se trata. En cuanto a la Jurisprudencia de esta Sala sobre el valor de la costumbre en esta materia, la Sentencia del Tribunal Supremo de 10 de julio de 1989, referida al aprovechamiento comunal de unos montes, afirma que "no siendo posible la explotación colectiva ante todo habrá que acudir a dicha fuente (costumbre) (...) ha de entenderse que la costumbre tiene prioridad sobre la ordenanza local. Este es el orden que dibuja el texto refundido de 1986 art. 75.2- y aunque el hoy vigente Reglamento de Bienes en su artículo 95 incluye en primer término las ordenanzas y después las normas consuetudinarias hay que entender como ya se ha dicho que la primacía es la señalada tanto por rango legal del texto refundido como por los antecedentes históricos de la figura que se examina". Enlazando esta última cita de los antecedentes históricos con lo acontecido en la regulación tradicional de estos aprovechamientos de bienes co-
} 
Por su parte, la sentencia del Tribunal Supremo de 21 de febrero de 2007, Sala de lo Contencioso-Administrativo, Sección $4^{\text {a }}$ (RJ 2007\2903) considera improcedente la modificación de una Ordenanza local que incorpora a su texto escrito la costumbre inveterada sobre la distribución de los beneficios obtenidos de los aprovechamientos forestales sobre bienes comunales de la localidad ${ }^{96}$.

munales, es claro que debe prevalecer la costumbre local contenida en las Ordenanzas, y que esa costumbre puede establecer condiciones de vinculación a la localidad que van más allá del arraigo o de permanencia en la misma. Así resulta ya de la Exposición de Motivos del Real Decreto de 8 de abril de 1930 hasta la publicación de la Ley 7/1985, de 2 de abril, y de su posterior Texto Refundido. En el supuesto concreto que nos ocupa, la Ordenanza fue objeto de una modificación parcial en 1986 si bien mantuvo el requisito de ser natural de la villa para el disfrute de los aprovechamientos. La cuestión se centra pues en resolver si la Ordenanza es o no conforme a Derecho cuando exige para obtener el disfrute de los aprovechamientos que quien se beneficie de ello sea natural de la localidad, requisito que se incorporó a la Ordenanza aprobada en 1972 y que respondía a la costumbre local y que venía a proteger el disfrute de esos bienes a favor del común para evitar los abusos que se denunciaban en la Ley de 23 de diciembre de 1948 y a los que con antelación se había referido el Real Decreto de 8 de abril de 1930. Ese requisito es perfectamente conforme a lo dispuesto en los artículos 75.4 del TRRL y 103.2 del Reglamento de Bienes, que se refieren a "determinadas condiciones de vinculación y arraigo o de permanencia". Sin duda la vinculación, el arraigo y la permanencia son exigencias perfectamente lícitas y ninguna lo es más en lo referente a la vinculación, que la relativa al nacimiento en el lugar, a la que se yuxtaponen, por lo que se refiere al arraigo o permanencia, la vecindad y la residencia continuada. Por lo expuesto, considera el Alto Tribunal que la Ordenanza es conforme a Derecho cuando exige para el disfrute de los aprovechamientos de los bienes comunales el requisito de ser natural de la localidad. También esa exigencia es conforme con la Jurisprudencia del Tribunal Supremo invocada por la defensa de la Corporación como la de la Sentencia de 15 de noviembre de 1962, así como las más recientes Sentencias de 11 y 24 de abril de 2000 en las que se ha aceptado la costumbre local incorporada a las Ordenanzas aprobadas cumpliendo los requisitos exigidos por la norma y que permiten la exigencia de esos requisitos de vinculación, arraigo y permanencia, entre los que se encuentra el de ser natural de la localidad que incluye la Ordenanza. Por todo lo dicho, el motivo se estima declarando nula la Sentencia de instancia y sin ningún valor ni efecto en el particular en que afirmó que la Ordenanza no podía incluir esa exigencia para el disfrute del aprovechamiento de los bienes comunales de ser natural de la localidad, que es conforme a Derecho.

${ }^{96}$ Extractando la mentada sentencia de 21 de febrero de 2007 debe señalarse que en ella el Tribunal Supremo estima el recurso de casación interpuesto contra la sentencia del TSJ Castilla-León de fecha 10 de junio de 2003 que expuso las cuestiones que la demanda planteaba frente a la Ordenanza recurrida, fundamentalmente que el reparto de lotes no ha respetado la costumbre local, refiriéndose al conflicto que puede surgir entre la regulación contenida en una Ordenanza y la costumbre local y cuál de ellas ha de prevalecer. La motivación del recurso de casación ante el Tribunal Supremo se fundamenta en la infracción del art. 75.2 del TRRL, por inaplicación o por interpretación errónea, basándose en la prioridad de la costumbre sobre las Ordenanzas que otorga dicho precepto, y, con apoyo asimismo en el número 4 de dicho precepto, se afirma que cualquier Ordenanza local reguladora del aprovechamiento de bienes comunales que no se ajuste a la costumbre local ha de ser declarada ilegal y sosteniéndose además que la costumbre vigente en la localidad, en cuanto al reparto de lotes entre los vecinos con derecho al aprovechamiento en el municipio, se recogió expresa y pacíficamente en la Ordenanza promulgada en 1949, y que esa costumbre no vulnera el Ordenamiento Jurídico y sólo podría modificarse si contraviniera algún derecho fundamental reconocido en la Constitución. Para examinar dicha motivación recuerda el Alto Tribunal los artículos. 132.1 de la Constitución, 5.1 de la Ley 33/2003, de 3 de noviembre, del Patrimonio de las Administraciones Públicas, 79.2 y 3 de la LBRL, 2.3 y 1.2 del Reglamento de Bienes de las En- 
Supuesto distinto del aprovechamiento de los bienes comunales lo constituye el que contempla la Ley 1/1970, de 4 de abril, de Caza (RCL 1970 \579) que, en relación a la propiedad de las piezas de caza determina en su artículo 22.6 que "Cuando haya duda respecto a la propiedad de las piezas de caza, se aplicarán los usos y costumbres del lugar. En su defecto, la propiedad corresponderá al cazador que le hubiere dado muerte cuando se trate de caza menor, y al autor de la primera sangre cuando se trate de caza mayor", y el Decreto 506/1971, de 25 de marzo, por el que se aprueba el Reglamento para la ejecución de la Ley de Caza de 1970 (RCL 1971\641) que en su artículo 24.6

tidades Locales, 1.1 y 1.3 del Código Civil, que certifican la existencia de la costumbre como fuente en el Derecho Administrativo que se pone de relieve en nuestro régimen local en artículos como el 29 de la Ley de Bases y el 53 del Texto Refundido, y 111 y 143 y 144 del Reglamento de Organización, Funcionamiento y Régimen Jurídico de las Corporaciones Locales que, referidos al funcionamiento del Concejo Abierto, disponen que ajusta su funcionamiento a los usos, costumbres y tradiciones locales y, en su defecto, a lo establecido en esta Ley y en las Leyes de las Comunidades Autónomas sobre régimen local. Pues bien, eso mismo ocurre en relación con los bienes comunales y la referencia que en relación con su aprovechamiento y disfrute contiene el art. 75.2 del TRRL cuando afirma que si este aprovechamiento y disfrute general simultáneo de bienes comunales fuere impracticable, regirá la costumbre u ordenanza local. La costumbre está presente, pues, en nuestro ordenamiento y, sobre aprovechamientos de bienes comunales, se recoge también el art. 95 del Reglamento de Bienes. Sentado esto, la sentencia del Alto Tribunal señala que, si bien la sociedad española ha sido siempre rural y los bienes comunales eran la garantía de la supervivencia de su población, es cierto que las circunstancias han cambiado, no obstante lo cual, en la villa de Canicosa de la Sierra (Burgos) las circunstancias es posible que no fueran muy distintas en 1998 y en 1949, tratándose de una zona que sigue manteniendo prácticamente las circunstancias socioeconómicas que existían cuando se les otorgó el privilegio de los aprovechamientos comunales por el Rey Carlos IV, de ahí las costumbres seculares en la distribución de los lotes reflejadas en la Ordenanza de 1949, por lo que la Ordenanza de 1998 alteró la costumbre que los habitantes de la villa se habían otorgado en la distribución de los lotes entre los vecinos. Partiendo de ello, se rechaza el argumento que sostiene que, como la costumbre se incluyó en una Ordenanza, puede ser modificada cuando concurran motivos para ello, porque si no se petrificaría el Ordenamiento Jurídico haciéndolo inmutable, situación que no sería conforme con la realidad social del tiempo en que aquellas han de ser aplicadas, de modo que si cambian las circunstancias es perfectamente posible alterarlas para adaptarlas al espíritu y finalidad al que deben servir; y se rechaza esta idea en base a que el que la costumbre adquiera rango de norma escrita no le priva de su condición y por ello no permite su modificación sin más, toda vez que la costumbre sólo se puede modificar cuando mute la "opinio iuris vel necesitatis" de la comunidad que la recibió como tal, y atendidas las circunstancias que así lo demuestren. Igualmente se rechaza la segunda de las razones que se ofrecen para justificar la modificación de la Ordenanza cambiando el modo de distribución de los lotes entre los vecinos, cual es la influencia de la Constitución de 1978 en todos los aspectos del Ordenamiento Jurídico y dada la fuerza expansiva del Texto Constitucional, toda vez que, con ser ello cierto, la necesidad de adaptación a la Constitución no puede ser absoluta haciendo tabla rasa de cuanto exista si su pervivencia no contraría cuestiones esenciales contenidas en el Texto Constitucional. La entrada en vigor de la Constitución no puede justificar sin más el cambio de la Ordenanza, salvo que existan razones suficientes para entender que la regulación es manifiestamente contraria a ella al producirse una inconstitucionalidad sobrevenida de la costumbre y sus razones plasmadas en la Ordenanza. En consecuencia entiende el Tribunal Supremo que ninguna razón había en 1998, fecha de la aprobación de la Ordenanza, que aconsejase modificar la misma cambiando el modo de distribución de los aprovechamientos comunales consuetudinaria y tradicionalmente establecido en la localidad, por lo que anula el artículo $3^{\circ}$ de la Ordenanza y restablece la costumbre en la distribución de aquellos que aplicaba la Ordenanza de 1949. 
dispone asimismo que "Cuando haya duda respecto a la propiedad de las piezas de caza, se aplicarán los usos y costumbres del lugar. En su defecto, el derecho de propiedad sobre la pieza cobrada corresponderá al cazador que la hubiera dado muerte, cuando se trate de caza menor, y al autor de la primera sangre, cuando se trate de caza mayor. Tratándose de aves en vuelo, la propiedad de las piezas de caza corresponderá al cazador que las hubiere abatido". En definitiva, ambas normas remiten los criterios para determinar la propiedad de las piezas de caza primeramente a los usos y costumbres del lugar.

En los distintos supuestos hasta aquí analizados la costumbre no aparece como fuente supletoria, sino que eleva su rango hasta ocupar el que le asigna la norma remitente, que, se ha visto cómo incluso invoca la costumbre como solución previa a la aplicación de la propia norma. Se trata pues de costumbre extra legem que opera como fuente en virtud de una expresa remisión a la misma efectuada por la norma escrita.

B) Costumbre extra legem que opera como fuente supletoria en ausencia de remisión legal expresa

En lo que respecta a la costumbre extra legem que actúa como fuente supletoria de la ley en ausencia de remisión legal expresa, esto es, aquélla que nace del uso seguido en las relaciones entre particulares en la conformación del Derecho Administrativo, debe señalarse que su presencia es menor, aunque no inexistente, no obstante lo cual, en un concreto caso de inscripción de aprovechamiento de aguas respecto a la que los regantes pretendían contar con un caudal mayor del concedido, se determinó por el Tribunal Supremo que, aunque en el título jurídico no constare el número de litros por segundo aprovechados, se suele autorizar a inscribir por el Ministerio de Obras Públicas como mínimo un litro por hectárea de tierra regable, lo que constituye una práctica administrativa que colma la laguna jurídica que al efecto existe (sentencia del Tribunal Supremo de 3 de marzo de 1958, RJ 1958\957).

En otro concreto supuesto relativo a la práctica de los exámenes en la Universidad, se afirmó por el Tribunal Supremo, en el caso del examen de un alumno, que, ante la inexistencia de una ordenación positiva específica sobre la práctica de los exámenes académicos, había que seguir la costumbre, que es fuente del Derecho, según el artículo 6 del Código Civil, en defecto de ley, extensivo al Derecho especial como es el Derecho Administrativo, siendo lo consuetudinario que sean los catedráticos o profesores especialistas encargados de cátedra los que dirijan e intervengan directamente en los exámenes de las disciplinas académicas que desempeñan (sentencia del Tribunal Supremo de 15 de marzo de 1963, RJ 1963\1676). 
Podría tener encaje asimismo entre estos supuestos el de la existencia de la institución de los somatenes ${ }^{97}$. Se trata en origen de una institución catalana de carácter parapolicial, un cuerpo armado de autoprotección civil, separado del ejército, para la propia defensa y la de la tierra. Sus inicios provienen del sagramental, cuyos orígenes se encuentran en las recopilaciones efectuadas por las Cortes de Cataluña en 1068 y de un usatge denominado Princeps namque ${ }^{98}$. Ambos textos legales configuran el carácter a la vez policial, en el ámbito local, y militar, en el general, conferido al somatén. Es pues, una policía privada designada por el pueblo pero con autoridad, siendo sus miembros todos los vecinos en condiciones de prestar tal servicio. Entre sus funciones se encontraban dar la alarma para alertar a los pueblos vecinos ${ }^{99}$, asimismo tenían la obligación de conservar armas en sus casas y de instruirse periódicamente en su manejo. La historia del somatén ${ }^{100}$ está plagada de sucesivas presencias y supresiones, adquiriendo en los siglos XVI y XVII un papel fundamentalmente policial, sien-

97 Somatén proviene del catalán "sometent", -de "so emetent"- que significa "emitiendo sonido", por los toques de campana que los convocaban.

98 Princeps namque es uno de los usatges de Barcelona que regulaba la defensa del príncipe y del Principado de Cataluña, así como la convocatoria a las armas. Incluido en los primeros usatges del siglo XI, fue invocado explícitamente hasta el siglo XVI. Derogado tras los Decretos de Nueva Planta, perduró no obstante en la institución del somatén.

${ }^{99}$ Esto se llevaba a cabo mediante hogueras encendidas de cumbre a cumbre, el sonido de un cuerno, un toque de trompeta o repique de campanas. De esta última manera, del repique de campanas (o bien so emetent, en catalán) es de donde surge el nombre posterior, que prevalece sobre el de sagramental a partir sobre todo del siglo XVI.

${ }^{100}$ La presencia del somatén en la historia de España puede constatarse a partir del hecho de que la movilización masiva de los ciudadanos se denominaba "somatén general" y alcanzó su auge durante los siglos XII y XIII, siendo frecuente aún en los siglos XIV y XV. Es en los siglos XVI y XVII cuando adquiere un papel fundamentalmente policial -contra bandoleros, hugonotes y piratas- definido por la Constitución de 1561, vigente hasta mediados del siglo XVII. A raíz de la derrota de los partidarios catalanes del archiduque Carlos en la Guerra de Sucesión Española (1714), Felipe V promulga los Decretos de Nueva Planta, uno de cuyos efectos es la supresión del somatén, liderado por el general Moragues durante la guerra. Pese a esta supresión temporal, el somatén fue restablecido en 1794 por el conde de la Unión durante la Guerra del Rosellón (1793-1795), a causa sobre todo de la mala situación del ejército. Fue nuevamente usado durante la Guerra de la Independencia Española (1808-1814), en contra de los franceses en Rosas, Barcelona y Tarragona. En 1855 fue reconstituido por los grandes propietarios rurales, con el nombre de Sometent Armat de la Muntanya de Catalunya y adoptó el lema de Pau, pau i sempre pau (paz, paz y siempre paz). A partir de entonces, el somatén adquirió un carácter de cuerpo auxiliar del orden público en el ámbito rural, destinado a proteger los dominios de los grandes propietarios. Se abolió nuevamente en la Primera República, pero se restableció poco después para combatir a los carlistas en la Tercera Guerra Carlista. Las Bases de Manresa reservaban al somatén una importante tarea, que no se llegó a llevar a término por no aplicarse. Posteriormente, el somatén actuó en colaboración con las autoridades en varias ocasiones. Así, por ejemplo, colaboraron en la detención del pedagogo Francisco Ferrer Guardia (1909), acusado de complicidad en el atentado de Mateo Morral contra Alfonso XIII, y en contra de los huelguistas en Alella, en los años anteriores a la dictadura de Primo de Rivera. El apoyo popular del somatén era escaso, debido a su actividad represiva y de trato favoritista con las clases altas, gestándose to- 
do suprimido por los Decretos de Nueva Planta promulgados por Felipe V, siendo nuevamente restablecido en 1794 como consecuencia de la pésima situación del ejército. A partir de 1855 el somatén adquirió un carácter de cuerpo auxiliar del orden público en el ámbito rural, destinado a proteger los dominios de los grandes propietarios. Se abolió nuevamente en la Primera República, pero se restableció poco después para combatir a los carlistas en la Tercera Guerra Carlista. Nuevamente disuelto en 1931 por la Segunda República, se restableció otra vez en 1936 tras la sublevación que originó la Guerra Givil. Acabada ésta, en 1939, se disuelve nuevamente el somatén, aunque no sería por mucho tiempo, ya que en 1945 el gobierno del general Franco lo reorganiza, extendido ya a casi todo el territorio español, bajo el nombre de "Somatén Armado", con la finalidad principal de colaborar con la Guardia Civil en combatir a los maquis y a las organizaciones obreras clandestinas. Los miembros del somatén, que tenían sus fusiles adjudicados en los puestos de la Guardia Civil y licencia de arma corta, aunque no podían actuar en solitario, sí podían quedar a cargo del cuartel de la Guardia Civil en caso de que fuese necesario que todos los guardias acudieran a una emergencia, y también podían salir de servicio formando pareja con un guardia civil. Su disolución se produce definitivamente en 1978, por Real Decreto 2333/1978, de 25 de agosto, por el que se disuelven los somatenes armados ${ }^{101}$, reconociéndose en su preámbulo su "larga tradición en la legislación española, como unidades constituidas por ciudadanos civiles que se presentaban desinteresadamente a colaborar en funciones de auxilio a la paz ciudadana y a la custodia de propiedades en el ámbito rural, bajo la dependencia de las fuerzas de orden público", justificando su disolución en el hecho de que "Si bien por la carencia o escasez de efectivos

\footnotetext{
da un leyenda negra a su alrededor. En 1931 es disuelto de nuevo por la Segunda República, debido a sus tendencias conservadoras, pero se restableció en 1936 tras la sublevación que originó la Guerra Civil. Acabada ésta, en 1939, se disuelve nuevamente el somatén, pero no por mucho tiempo, puesto que en 1945 el gobierno del general Franco lo reorganiza, extendido ya a casi todo el territorio español, bajo el nombre de "Somatén Armado", con la finalidad principal de colaborar con la Guardia Civil en combatir a los maquis y las organizaciones obreras clandestinas. Los miembros del somatén, que tenían sus fusiles adjudicados en los puestos de la Guardia Civil y licencia de arma corta (muy limitada en España), no podían actuar en solitario, pero podían quedar a cargo del cuartel de la Guardia Civil si era necesario que todos los guardias acudieran a una emergencia, o salir de servicio formando pareja con un guardia civil. Fue disuelto definitivamente en 1978 por Real Decreto 2333/1978, de 25 de agosto, por el que se disuelven los somatenes armados. Aun así perduraron hasta la década de los 80. En la actualidad, el somatén es sólo reconocido en Andorra como institución oficial, aunque sólo entra en servicio durante emergencias nacionales como las inundaciones de 1982 o en actos oficiales como la visita del Presidente de la República Francesa y el Obispo de Urgell en calidad de copríncipes de Andorra, llamándose a leva a todos los andorranos varones mayores de 18 años. No tiene ningún otro uso ni permanencia mayor, ya que la seguridad interior es competencia de la policía andorrana y, en caso de violación o amenaza de la soberanía, independencia o integridad del territorio andorrano, de España y de Francia.

${ }^{101}$ Boletín Oficial del Estado núm. 234, de 30 de septiembre de 1978.
} 
regulares y profesionales, los somatenes pudieron realizar en su momento servicios muy estimable, las circunstancias actuales permiten y hacen necesario que estas tareas sean desempeñadas en exclusiva por los cuerpos de seguridad", el mentado Real Decreto derogó los Decretos de 21 de enero de 1936 y de 9 de octubre de 1945 sobre Somatenes Armados y estableció que los comandantes de puesto de la Guardia Civil harían entrega a la Jefatura de Armamento de la Dirección General de la Guardia Civil de la totalidad de las armas largas y municiones para uso del somatén de que fueren depositarios, quedando sin valor ni efecto e incursas en caducidad a partir del 1 de enero de 1979 la totalidad de las licencias para uso de arma corta de que fueran titulares los somatenistas en virtud de su condición de tales.

En otro orden de cosas debe apuntarse dentro de este apartado la posibilidad de aplicación de las costumbres y usos mercantiles ${ }^{102}$ a las Sociedades mercantiles de la Administración Pública en el marco de su consideración como Administración institucional. En la legislación mercantil española los usos del comercio constituyen una de las fuentes generales directas del Derecho Mercantil que se admite por el legislador en segundo lugar, en defecto de las disposiciones contenidas en el Código de Comercio y con preferencia sobre el Derecho común. Así lo establece expresamente el artículo 2 del Código de Comercio aprobado por Real Decreto de 22 de agosto de 1885 (LEG $1885 \backslash 21)$ que dispone que "Los actos de comercio, sean o no comerciantes los que los ejecuten, y estén o no especificados en este Código, se regirán por las disposiciones contenidas en él; en su defecto, por los usos del comercio observados generalmente en cada plaza; y a falta de ambas reglas, por las del Derecho común. Serán reputados actos de comercio los comprendidos en este Código y cualesquiera otros de naturaleza análoga", por lo que debe afirmarse la preeminencia de la costumbre mercantil sobre el Derecho común. Sentado esto, la posible extrapolación de los usos comúnmente observados y a los que da vida el comercio, a las Sociedades mercantiles de las Administraciones Públicas debe examinarse desde la perspectiva de que, pa-

\footnotetext{
102 Se denominan indistintamente usos del comercio, usos mercantiles y práctica comercial, a las normas jurídicas y reglas de interpretación producidas espontáneamente en la vida del comercio mediante la repetición continuada de actos de la misma clase, que sirven para resolver los conflictos jurídicos de carácter mercantil cuando no existe principio legal aplicable y para suplir cláusulas, fijar el sentido de las palabras y conceptos o dar al acto comercial el efecto que naturalmente debe tener. A pesar de la usual asimilación de costumbres y usos mercantiles, ÁLVAREZ DEL MANZANO sostiene la distinción completa entre uso y costumbre mercantil, siendo el primero la causa y el segundo el efecto, concretamente dice "El uso es simple práctica o repetición continuada de actos de una misma clase, y la costumbre es Derecho introducido por esa misma repetición o práctica; el uso no es Derecho, y, por consiguiente, podrá interpretar, pero no derogar el Derecho, y la costumbre es un nuevo Derecho, e interpreta y deroga el Derecho establecido. Queda, pues, el valor jurídico del uso limitado al de una regla de interpretación de importancia inmensa en el comercio" (ÁLVAREZ DEL MANZANO, Faustino, Curso de Derecho mercantil filosófico, histórico y vigente (español y extranjero), tomo I, 2a ed., Lib. Victoriano Suárez, Madrid, 1903, pág. 130).
} 
ra el caso del Estado, sólo se les atribuye tal carácter a aquéllas en que la Administración General del Estado o sus Organismos Públicos cuentan con una participación mayoritaria, directa o indirecta de su capital, o cuyo capital sea íntegramente público. La Ley 6/1997, de 14 de abril, de Organización y Funcionamiento de la Administración General del Estado (RCL 1997\879) establece en su Disposición Adicional Duodécima que: "1. Las Sociedades Mercantiles estatales se regirán integramente, cualquiera que sea su forma jurídica, por el ordenamiento jurídico privado, salvo en las materias en que les sean de aplicación la normativa presupuestaria, contable, patrimonial, de control financiero y contratación. En ningún caso podrán disponer de facultades que impliquen el ejercicio de autoridad pública. 2. Las Sociedades Mercantiles estatales, con forma de sociedad anónima, cuyo capital sea en su totalidad de titularidad, directa o indirecta, de la Administración General del Estado o de sus Organismos públicos, se regirán por el título VII de la Ley del Patrimonio de las Administraciones Públicas ${ }^{103}$ y por el ordenamiento jurídico privado, salvo en las materias en que les sean de aplicación la normativa presupuestaria, contable, de control financiero y de contratación". Como estas Sociedades operan en el mercado en un plano de igualdad de condiciones con respecto a las demás sociedades mercantiles privadas, estas entidades se van a regir íntegramente por el Derecho Mercantil, a excepción de lo relativo a las materias en que les sean de aplicación la normativa presupuestaria, contable, patrimonial, de control financiero y contratación, podrían aplicársele en la misma medida que a éstas las costumbres o usos mercantiles observados generalmente, lo cual también procedería aún en el caso de que se trate de Sociedades mercantiles bajo la forma de Sociedad Anónima, cuyo capital pertenezca íntegramente a la Administración General del Estado o sus Organismos públicos, entre los que se ubican los entes de gestión con forma organizatoria de Sociedad mercantil, cuyo régimen se acerca al de las Entidades públicas empresariales ${ }^{104}$, y se rigen por el Título VII de la Ley del Patrimonio de las Administraciones Públicas y por el ordenamiento jurídico privado, con las mismas salvedades antes expuestas, esto es, en las materias en que les sean de aplicación la normativa presupuestaria, contable, de control financiero y de contratación. En el ámbito local, tal y como dispone el artículo 85 ter de la Ley 7/1985, de 2 de abril, de Bases de Ré-

103 Ley 33/2003, de 3 de noviembre, de Patrimonio de las Administraciones Públicas (RCL 2003\2594).

${ }^{104}$ Según el artículo 53 de la Ley 6/1997, de 14 de abril, de Organización y Funcionamiento de la Administración General del Estado: "1. Las entidades públicas empresariales son Organismos públicos a los que se encomienda la realización de actividades prestacionales, la gestión de servicios o la producción de bienes de interés público susceptibles de contraprestación. 2. Las entidades públicas empresariales se rigen por el Derecho privado, excepto en la formación de la voluntad de sus órganos, en el ejercicio de las potestades administrativas que tengan atribuidas y en los aspectos especificamente regulados para las mismas en esta Ley, en sus estatutos y en la legislación presupuestaria”. 
gimen Local, "1. Las sociedades mercantiles locales se regirán integramente, cualquiera que sea su forma jurídica, por el ordenamiento jurídico privado, salvo las materias en que les sea de aplicación la normativa presupuestaria, contable, de control financiero, de control de eficacia y contratación, y sin perjuicio de lo señalado en el apartado siguiente de este artículo. 2. La sociedad deberá adoptar una de las formas de sociedad mercantil de responsabilidad limitada, y en la escritura de constitución constará el capital, que deberá ser aportado integramente por la entidad local o un ente público de la misma. 3. Los estatutos determinarán la forma de designación y el funcionamiento de la funta General y del Consejo de Administración, así como los máximos órganos de dirección de las mismas", por lo que puede llegarse a idénticas conclusiones respecto a los usos mercantiles.

Asimismo es práctica inmemorial en muchos municipios que los comerciantes concurran en un determinado día a expender sus mercancías, habiendo regido, para el debido orden de las transacciones, alineación de puestos, etc., inveteradas costumbres que han sido conservadas con escrupulosidad por las autoridades municipales ${ }^{105}$.

Finalmente puede referirse en este apartado otro modelo bien diferente de costumbre que se desarrollaba en el ámbito local, cual era el del alumbrado de las imágenes, que sirvió de base para lo que posteriormente se convertiría en el alumbrado público municipal de las localidades ${ }^{106}$.

En definitiva, existen prácticas locales de uso constante que, no hallándose en contraposición con el Derecho escrito, pueden llegar a tener fuerza de ley, constituyendo, por decirlo así, Derecho consuetudinario local ${ }^{107} 108$.

C) Supuestos de costumbre contra legem: su carencia de validez

Expuesto ya que la costumbre contra legem no tiene viabilidad en Derecho Administrativo, e independientemente de lo expresado supra, queda no obs-

105 Enciclopedia Jurídica Española, Seix, op. cit., Tomo Noveno, págs. 817 y 818.

106 Enciclopedia Jurídica Española, Seix, Barcelona, 1910, Tomo Noveno, pág. 817.

107 Según se establece en la Novísima Recopilación de las Leyes de España de 1806 las costumbres de los pueblos deberán respetarse y guardarse sin entorpecimiento, tanto es así que el artículo 585 del Código Penal de 1870 (Gaceta de Madrid núm. 158, de 31 de agosto de 1870) reservaba su párrafo segundo a tal prescripción, castigando las infracciones relativas a las mismas.

108 Independientemente de estas costumbres enraizadas en el ámbito local no puede dejar de hacerse referencia a ciertas prácticas que antaño se realizaban con frecuencia en actuaciones con la Administración como el hecho de comunicarse por carta, equivaliendo ello a una solicitud, siendo también usuales las decisiones verbales y autorizaciones de palabra en municipios pequeños, así como la celebración de improvisados referendums a los vecinos. 
tante hacer referencia a la posibilidad de su existencia a pesar de su carencia de valor, toda vez que existe constancia de concretos supuestos como los que a continuación se expresan. Aunque mayormente relacionado con el ordenamiento jurídico tributario, el primero de ellos se refiere al uso del papel sellado en el Valle de Arán, estando en su momento expresamente declarada por la Administración la improcedencia de esta costumbre contra legem, concretamente se dispone que "esta Dirección General, con fecha 23 de enero último, y, de conformidad con lo informado por la de lo Contencioso del Estado, ha acordado declarar que el privilegio de que disfrutaba el Valle de Arán, otorgado por don Fuan I de Aragón en 1387, está derogado expresamente por la RO de 27 de julio de 1898 e implícitamente, por la Ley del Timbre, que establece excepciones a favor de las provincias Vascongadas y Navarra, y nada dice del Valle de Arán; que el hecho de que en éste no se satisfaga el impuesto no tiene fuerza legal en contra de las disposiciones citadas, toda vez que según el artículo $5^{\circ}$ del Código Civil de aplicación en todo el territorio nacional, según el párrafo 1 del artículo 12, las leyes sólo se derogan por otras posteriores y no prevalecerá contra su observancia el desuso ni la costumbre o la práctica en contrario; y que, en consecuencia, la legislación vigente respecto al impuesto del timbre, es aplicable al Valle de Arán, sin que el uso de papel sellado en dicha comarca tenga validez en contra de los preceptos legales aplicables al caso" ${ }^{\prime 109}$.

El segundo de los supuestos es el que aborda la cuestión de la importación de embarcaciones deportivas en las Islas Canarias, respecto a la que no se permite la invocación de la costumbre contraria a la ley. Señala la sentencia del Tribunal Supremo de 3 de mayo de 1979110 , "Oue cuando la Ley habla de srégimen actualmente vigente», ha de entenderse como tal el «régimen legal» puesto que nos hallamos ante una exención fiscal, y por lo tanto y como antes se ha razonado, tenía que ser concedida por Ley y contra ella no podía prevalecer la costumbre o la práctica en contrario"111112. Aun cuando este rechazo de la costumbre contra legem se produce en el ámbito de la procedencia de una exención tributaria, valga su exposición a los efectos ejemplificativos que aquí interesan en pro de la carencia de validez de este tipo de costumbre asimismo en el Derecho Administrativo.

109 A este respecto, vid., DANÉS I TORRAS, Daniel, El valle de Arán y el papel sellado. Contribución al estudio y defensa de una exención tributaria, Barcelona, 1959, y GARCÍA DE TOLEDO, "Posibilidad de considerar la pervivencia de la exención, concedida por el Privilegio de la Querimonia, en relación con el vigente Impuesto sobre Actos Jurídicos Documentados", Anales de la Dirección General de lo Contencioso del Estado, 1978, pág. 531 y sigs.

110 Sala de lo Contencioso-Administrativo (RJ 1979\1926).

111 Considerando Sexto.

112 En el mismo sentido, vid., las sentencias de la Sala de lo Contencioso-Administrativo del Tribunal Supremo de 1 de abril de 1981 (RJ 1981 \1436) y de 29 de mayo de 1982 (RJ 1982\2821). 


\section{CONCLUSIONES}

Permitiendo pues la perspectiva estatutaria entender la importancia de la costumbre como fuente del Derecho Administrativo, toda vez que permite la superación del enfoque del Estado como simple aparato organizado para el ejercicio del poder y, como tal, único protagonista de la producción del Derecho, la presencia de la colectividad social en el sistema de producción de fuentes es innegable. Partiendo de ello, y, aún a pesar de su limitada presencia en Derecho Administrativo, la costumbre únicamente admisible en nuestro Derecho va a ser la extra legem o praeter legem, esto es, aquella que va a operar como fuente en virtud de remisión expresa por ley escrita y la que va a operar como fuente supletoria en ausencia de remisión legal expresa. Entre los supuestos de la primera de ambas modalidades pueden aislarse y distinguirse las auténticas normas consuetudinarias en Derecho Administrativo y que surgen verdaderamente cuando el legislador se remite directamente a ellas considerándolas pura y simplemente como costumbre. Así puede encontrarse en la legislación administrativa de sectores concretos una expresa referencia a la costumbre, inclusive previa y prioritaria a la aplicación de la ley. En los distintos supuestos aquí analizados la costumbre no aparece como fuente supletoria, sino que eleva su rango hasta ocupar el que le asigna la norma remitente, que, se ha visto cómo incluso invoca la costumbre como solución previa a la aplicación de la propia norma. Se trata pues de costumbre extra legem que opera como fuente en virtud de una expresa remisión a la misma efectuada por la norma escrita. Mientras que entre los supuestos de la segunda modalidad referida en la que la costumbre actúa como fuente supletoria de la ley en ausencia de remisión legal expresa, esto es, aquélla que nace del uso seguido en las relaciones entre particulares en la conformación del Derecho Administrativo, debe señalarse que su presencia es o ha sido menor, aunque no inexistente. En definitiva, debe reconocerse la existencia de la costumbre -mayormente local- que pervive y convive con la ordenación positiva como exponente de la conciencia jurídica del pueblo y que como tal tiene contrastada presencia en distintos sectores e instituciones del Derecho Administrativo. 


\section{BIBLIOGRAFÍA}

ÁLVAREZ DEL MANZANO, Faustino, Curso de Derecho mercantil filosófico, histórico y vigente (español y extranjero), tomo I, $2^{\text {a }}$ ed., Lib. Victoriano Suárez, Madrid, 1903.

BASSOLS COMA, Martín, "Reflexiones sobre el nuevo título preliminar del Código Civil; planteamientos jurídico-administrativos", Revista Española de Derecho Administrativo, núm. 11, 1976.

BIELSA, Rafael, Legislación administrativa argentina, tomo I, Buenos Aires, 1938. BOBBIO, Norberto, La consuetudine como fatto normativo, Padova, 1940.

BORRULL Y VILANOVA, Francisco Xavier, Discurso sobre la distribución de las aguas del Turia y deber conservarse el Tribunal de los acequieros de Valencia, Imprenta de D. Benito Monfort, Valencia, 1928.

CARRETERO Y JIMÉNEZ, Anselmo, "Comunidad de villa y tierra, núcleo básico de la federación medieval castellana", La personalidad histórica de Castilla en el conjunto de los pueblos hispánicos, Hyspamérica de Ediciones, San Sebastián, 1977.

CASTÁN, José, Derecho Civil español, común y foral, Tomo I. Introducción y parte general, Vol. I. Ideas generales. Teoría de la norma jurídica, Madrid, 1951.

CLAVERO ARÉVALO, Manuel, "La doctrina de los principios generales del Derecho y las lagunas del ordenamiento administrativo", Revista de Administración Pública, núm. 7, enero-abril 1952.

COLMEIRO, Manuel, Derecho Administrativo español, tomo I, Imp. de Hilario Martínez, Madrid, 1850.

DANÉS I TORRAS, Daniel, El valle de Arán y el papel sellado. Contribución al estudio y defensa de una exención tributaria, Barcelona, 1959.

DE CASTRO, Federico, Derecho Civil de España, Parte general, I, Madrid, 1955.

ENNEGCERUS, Ludwig, Derecho Civil, Parte general, tomo I, Barcelona, 1934.

FERRARI, Giusepe, Introduzione allo Studio sul Diritto pubblico consuetudinario, Milano, 1950.

FORTI, U., Diritto Administrativo, vol. I, Napoli, 1931.

GARCÍA DE ENTERRÍA, Eduardo y FERNÁNDEZ RODRÍGUEZ, Tomás-Ramón, Curso de Derecho Administrativo, Tomo I, $15^{\text {a }}$ ed., Civitas, Madrid, 2011.

GARCÍA DE TOLEDO, "Posibilidad de considerar la pervivencia de la exención, concedida por el Privilegio de la Querimonia, en relación con el vigente Impuesto sobre Actos Jurídicos Documentados", Anales de la Dirección General de lo Contencioso del Estado, 1978.

GARCíA OVIEDO, Carlos, Derecho Administrativo, Madrid, 1953. 
GARRIDO FALLA, Fernando, "Las fuentes no escritas del Derecho en el Derecho Administrativo", Revista de Estudios de la Vida Local, núm. 97, enerofebrero 1958.

GARRIDO FALLA, Fernando, Tratado de Derecho Administrativo, vol. I, Madrid, 1980.

GASCÓN Y MARÍN, José, Tratado de Derecho Administrativo, vol. I, Madrid, 1941.

GIANNINI, Massimo Severo, Lezzioni di Diritto administrativo, vol. I, Milano, 1950.

GINER BOIRA, Vicente, El Tribunal de las Aguas de la Vega de Valencia, Ed. Giner Boira, Valencia, 1953.

GONZÁLEZ PÉREZ, Jesús, "El método en el Derecho Administrativo", Revista de Administración Pública, núm. 22, enero-abril 1957.

GUILLÉN RODRÍGUEZ DE CEPEDA, Antonio, El Tribunal de las Aguas de Valencia. Los modernos Jurados de riego: tesis doctoral, Est. Tipográfico Doménech, Valencia, 1920.

LAMBERT, Edouard, La fonction du Droit civil comparé, tomo I, V. Girad y E. Brière, París, 1903.

LONGO, A., Della consuetudine come fonte del diritto pubblico, Palermo, 1892.

MARTÍN-RETORTILLO BAQUER, Sebastián, El Derecho Civil en la génesis del Derecho Administrativo y de sus instituciones. Dos estudios, $1^{a}$ ed., Instituto García Oviedo, Universidad de Sevilla, Sevilla, 1960.

MAYER, Otto, Droit Administratif Allemand, vol. I, París, 1903.

MIELE, G., Principi di Diritto administrativo, tomo I, Padova, 1953.

MIELE, G., "Profilo della consuetudine nel sistema delle fonti del diritto interno", Stato e Diritto, 1943.

MORELL OCAÑA, Luis, "La costumbre y los principios jurídicos generales en el Derecho Administrativo", Documentación Administrativa, núm. 195, julio-septiembre 1982.

NIETO GARCíA, Alejandro, Bienes comunales, Ed. Revista de Derecho Privado, Madrid, 1964.

ORTIZ DÍAZ, José, "El precedente administrativo", Revista de Administración Pública, núm. 24, septiembre-diciembre 1957.

POSADA, Adolfo, Tratado de Derecho Administrativo, $2^{a}$ ed., Madrid, 1923.

PRESSUTTI, Enrico, Istituzioni di Diritto administrativo italiano, 2a ed., Roma, 1930.

RANELLETTI, Oreste, "La consuetudine come fonte del diritto pubblico interno", Revista di Diritto Pubblico, Milano, 1913.

REGLADE, M., La coutûme en droit public interne, Burdeos, 1919.

ROYO VILLANOVA, Antonio, Elementos de Derecho Administrativo, tomo I, $24^{a}$ ed., Valladolid, 1955. 
SANTAMARÍA PASTOR, Juan Alfonso y PAREJO ALFONSO, Luciano, Derecho Administrativo. La jurisprudencia del Tribunal Supremo, Madrid, 1989.

TESAURO, A., "Consuetudine", Rasegna di Diritto Pubblico, abril-junio 1955.

VALLS TABERNER, Fernando, El Tribunal de Lligalló de Morella, Imp. V. Carceller, Morella, 1926.

WALINE, Marcel, L'individualisme et le Droit, Ed. Domat-Montchrestien, 1949.

WERNER, Alain, "Le précédent administratif, source de légalité", AfJDA, núm. 7-8, 1987.

ZANOBINI, Guido, Corso di Diritto administrativo, vol. I, Milano, 1947. 